Article

\title{
Influence of the Background Nitrogen Oxides on the Tropospheric Ozone Depletion Events in the Arctic during Springtime
}

\author{
Jiashu Zhou, Le Cao * and Simeng Li \\ Key Laboratory for Aerosol-Cloud-Precipitation of China Meteorological Administration, \\ Nanjing University of Information Science and Technology, Nanjing 210044, China; \\ jiashu.zhou@nuist.edu.cn (J.Z.); Simeng.Li@nuist.edu.cn (S.L.) \\ * Correspondence: le.cao@nuist.edu.cn
}

\begin{abstract}
Ozone depletion events (ODEs) in the springtime of the Arctic have been frequently observed since the early 1980s, and the correlation between the ozone mixing ratio during the ODEs and the nitrogen oxides $\left(\mathrm{NO}_{\mathrm{x}}\right)$ concentration is still unclear. In the present study, the role of the background level of $\mathrm{NO}_{\mathrm{x}}$ in ODEs was investigated by using a box model implementing a chemical reaction mechanism containing 49 chemical species and 141 related reactions. A concentration sensitivity analysis was also applied to discover the dependence of the ozone mixing ratio during the ODEs on each constituent of the initial air composition. The simulation results showed that a critical value of the $\mathrm{NO}_{\mathrm{x}}$ background level exists, with which the ozone depletion rate is independent of the initial concentration of $\mathrm{NO}_{x}$, and the critical value was found to be approximately $55 \mathrm{ppt}$ (ppt $=$ part per trillion, $10^{-12} \mathrm{~mol} / \mathrm{mol}$ ) in the present study. The concentration sensitivity analysis also showed that the existence of $\mathrm{NO}_{x}$ has a two-sided impact on the depletion of ozone, depending on the initial amount of $\mathrm{NO}_{x}$. With a low background level of $\mathrm{NO}_{x}$ (less than $55 \mathrm{ppt}$ ), the increase of the initial $\mathrm{NO}_{\mathrm{x}}$ can advance the ozone depletion. On the contrary, with a high initial $\mathrm{NO}_{\mathrm{x}}$ level (more than $55 \mathrm{ppt}$ ), $\mathrm{NO}_{\mathrm{x}}$ would delay the consumption of ozone during the ODEs.
\end{abstract}

Keywords: concentration sensitivity analysis; ozone depletion events; nitrogen oxides

\section{Introduction}

Ozone is a trace gas of great significance in the atmosphere, which has an important influence on the global climate and environment [1-3]. It is a key factor affecting the dynamics, thermodynamics, radiation and chemical processes in the stratosphere and the troposphere. First of all, by absorbing ultraviolet (UV) radiation from the sun, ozone becomes the major heat source in the stratosphere and protects lives on Earth from harmful UV radiation [4,5]. Second, ozone is a strong oxidant, and its photolysis in the troposphere is the major source of $\mathrm{OH}$ radicals in the atmosphere. Thus, the distribution and the change of ozone directly affect the concentration and lifetime of other chemical species and $\mathrm{OH}$ radicals. Moreover, the tropospheric ozone is a pollutant, which can cause eye irritation and respiratory diseases [6-8]. The major sources of the tropospheric ozone are automobile emissions, power plants using fossil fuel and other human activities $[9,10]$. The mixing ratio of ozone in the troposphere has doubled since the early 20th century because of the increasing man-made emissions of nitrogen oxides and volatile organic compounds (VOCs) [11].

The depletion of ozone is always a core problem in many fields. There are different types of ozone depletion events in the stratosphere and the troposphere [12-14], among which the Antarctic ozone hole, discovered by Farman et al. [15], is the most-commonly ozone depletion phenomenon 
in the stratosphere. In the present study, we focused on tropospheric ozone depletion events (ODEs) occurring in polar regions. ODEs in the polar troposphere refer to a phenomenon where the amount of ozone in the boundary layer of polar regions decreases rapidly from a background level $(\sim 40 \mathrm{ppb}$, $\mathrm{ppb}=$ part per billion, $10^{-9} \mathrm{~mol} / \mathrm{mol}$ ) to less than $1 \mathrm{ppb}$ in a few days. These ODEs occur mostly in the spring of polar regions, from March to May in the Arctic [16] and from August to October in the Antarctic [17], when they are favored by light and low temperature conditions [18].The occurrence frequency of the ODEs also shows great variations between different years, and the inter-annual variability is partly attributable to the influence brought about by the western Pacific teleconnection pattern, especially in the 2000s [19].

Because ozone is a precursor of many atmospheric oxidants, the tropospheric ODEs exert a strong influence on the oxidation capacity of the atmosphere. During ODEs, the oxidation ability originally dominated by ozone is weakened, while the halogen species controls the oxidation ability [13]. This alters the reaction cycles and final products of many atmospheric reactions. For example, during ODEs, the enhanced halogen chemistry can effectively oxidize reactive gaseous mercury (RGM), making it settle from the atmosphere into snow more easily. After that, due to the drift of glaciers and the melt of the snow, the bio-availability of mercury is enhanced [20].

\subsection{Discovery of ODEs}

In the spring of 1978, Oltmans [21] observed a phenomenon at Barrow, Alaska that the amount of ozone in the boundary layer rapidly decreased from the background level ( $\sim 40 \mathrm{ppb})$ to less than $1 \mathrm{ppb}$ in a few days. The low concentration of ozone also lasted for several days until the local meteorological conditions significantly changed. Then in 1986, Bottenheim et al. [16] observed an analogous phenomenon at Alert, Canada, confirming the findings of Oltmans. They also found a strong negative correlation between the ozone mixing ratio and the bromine concentration during ODEs, which highlights the importance of bromine-related species for the destruction of ozone.

The correlation between the bromine species and the ozone destruction remained unclear until 1994. Hönninger and Platt [22] gave an explanation for the increase of bromine concentration in ODEs. They proposed that bromine atoms react with ozone, forming $\mathrm{BrO}$ as

$$
\mathrm{Br}+\mathrm{O}_{3} \rightarrow \mathrm{BrO}+\mathrm{O}_{2}
$$

and the self-reactions of $\mathrm{BrO}$ are able to form bromine atoms or molecular bromine through

$$
2 \mathrm{BrO} \rightarrow 2 \mathrm{Br}\left(\text { or } \mathrm{Br}_{2}\right)+\mathrm{O}_{2} .
$$

Under light conditions, bromine molecules photolyze and form bromine atoms again, continuously consuming ozone in the troposphere via

$$
\mathrm{Br}_{2}+\mathrm{h} v \rightarrow 2 \mathrm{Br} \text {. }
$$

In the series of (R1)-(R3), bromine acts as a catalyst.

Apart from these reactions, $\mathrm{BrO}$ can also be oxidized by free radicals in the atmosphere and form gas-phase hypobromous acid (HOBr) through

$$
\mathrm{BrO}+\mathrm{HO}_{2} \rightarrow \mathrm{HOBr}+\mathrm{O}_{2} .
$$

A following heterogeneous process with the participation of $\mathrm{HOBr}$ can activate bromide from various polar substrates such as the suspended aerosols and ice/snow-covered surfaces:

$$
\mathrm{HOBr}+\mathrm{H}^{+}+\mathrm{Br}^{-} \rightarrow \mathrm{Br}_{2}+\mathrm{H}_{2} \mathrm{O}
$$


leading to an explosive growth of the total bromine amount in the atmosphere and a rapid reduction of ozone in the boundary layer. This process is thus called "bromine explosion" mechanism [23-25].

As mentioned above, the tropospheric ODEs are favored under low temperature conditions [26]. However, the dependence of the ODEs on the temperature has not been fully clarified [27-29]. Lehrer et al. [18] and Koo et al. [29] proposed that a very strong temperature inversion is essential to the occurrence of ODEs because a stable boundary layer tends to be formed, leading to an accumulation of bromine and thus the destruction of ozone. Moreover, it was also suggested that wind shear [30,31], passage of lows [28], and a downward diffusion of warm air caused by the existence of clouds [32,33] may contribute to the termination of the ODEs. In general, the atmospheric conditions in which ODEs could occur in polar regions are still not clear.

\subsection{Role of Nitrogen Oxides in ODEs}

Investigations have been carried out into the relevant chemical reactions of gaseous halogens in the Arctic region for decades. However, the role of nitrogen oxides in the halogen cycle during ODEs is not relatively well-known.

The sources of nitrogen oxides in the Arctic are different from those in other regions, because the Arctic is sparsely populated and has few human activities. The typical $\mathrm{NO}_{\mathrm{x}}$ background level in the Arctic boundary layer ranges from $10 \mathrm{ppt}$ to $100 \mathrm{ppt}$, mainly due to photochemical products of snow [34], long-distance transport of organic nitrates from cities nearby [35], and emissions from international shipping with the thawing of the Northwest passage during warm seasons [36]. Thus, human-induced climate change will affect the amount of snow and ice cover in the Arctic, leading to a change in the intensity of nitrogen oxide emissions. In addition, oil exploitation and transportation activities in surrounding cities will increase the $\mathrm{NO}_{\mathrm{x}}$ transported to the Arctic, affecting the $\mathrm{NO}_{\mathrm{x}}$ level through atmospheric circulation.

Nitrogen oxides play an important role in the recycling of active free radicals (such as reactive halogens) in the atmosphere and indirectly affect ozone depletion. It controls the production of ozone through the titration reaction cycle:

$$
\begin{gathered}
\mathrm{NO}+\mathrm{O}_{3} \rightarrow \mathrm{NO}_{2}+\mathrm{O}_{2}, \\
\mathrm{NO}_{2}+\mathrm{h} v \rightarrow \mathrm{NO}+\mathrm{O}, \\
\mathrm{O}+\mathrm{O}_{2}(+\mathrm{M}) \rightarrow \mathrm{O}_{3}(+\mathrm{M}) .
\end{gathered}
$$

Nitrogen oxides can also react with halogens and are essential for the conversion between bromine compounds, and the ultimate sink for $\mathrm{NO}_{\mathrm{x}}$ is nitric acid $\left(\mathrm{HNO}_{3}\right)$ :

$$
\begin{gathered}
\mathrm{BrO}+\mathrm{NO} \rightarrow \mathrm{NO}_{2}+\mathrm{Br}, \\
\mathrm{BrO}+\mathrm{NO}_{2} \rightarrow \mathrm{BrONO}_{2}, \\
\mathrm{BrONO}_{2}+\mathrm{H}_{2} \mathrm{O} \stackrel{\mathrm{mp}}{\rightarrow} \mathrm{HOBr}+\mathrm{HNO}_{3}, \\
\mathrm{NO}_{2}+\mathrm{OH} \rightarrow \mathrm{HNO}_{3} .
\end{gathered}
$$

The abbreviation " $\mathrm{mp}$ " in (R11) denotes a multiphase reaction.

Since the early 1990s, box model calculations have shown that $\mathrm{NO}_{\mathrm{x}}$ is quickly lost during ODEs $[37,38]$. However, the correlation between the concentrate change of nitrogen oxides and ozone is relatively weak [39]. Analysis of TOPSE observation data in 2003 [40] shows that, in the early stage of ozone destruction, $\mathrm{NO}_{x}$ concentration decreases rapidly. However, when $\mathrm{O}_{3}$ dropped below $10 \mathrm{ppb}$, $\mathrm{NO}_{x}$ concentration recovered. Evans et al. [40] simulated this situation using a 0-D photochemical model, and attributed the initial $\mathrm{NO}_{x}$ consumption to the hydrolysis of $\mathrm{BrONO}_{2}$. They suggested that with the continuous decrease of $\mathrm{O}_{3}$, the ratio of $\mathrm{Br} / \mathrm{BrO}$ and $\mathrm{NO} / \mathrm{NO}_{2}$ increases. As a result, 
the $\mathrm{BrONO}_{2}$ formation through (R10) weakens, leading to a rate decrease of (R11) and (R12), which are sinks of $\mathrm{NO}_{\mathrm{x}}$. Then the release of $\mathrm{NO}_{\mathrm{x}}$ from the snow leads to a recovery of $\mathrm{NO}_{\mathrm{x}}$ in the ambient air. Thus, the intensity of this $\mathrm{NO}_{\mathrm{x}}$ recovery depends on the strength of the surface source, and thus may vary geographically and seasonally. The depletion of ozone also affects the life cycle of $\mathrm{NO}_{\mathrm{x}}$ and $\mathrm{HO}_{\mathrm{x}}$ radicals due to the enhancement of the bromine species. In 2010, Bloss et al. [41] used a box model to replicate the diurnal variation of $\mathrm{NO}$ and $\mathrm{NO}_{2}$ concentrations. They found that the halogen species will increase the $\mathrm{NO}_{2} / \mathrm{NO}$ ratio, and substantially reduce the $\mathrm{NO}_{\mathrm{x}}$ lifetime through heterogeneous loss of the halogen nitrates.

The role of nitrogen oxides in the tropospheric ODEs is also unclear. Some researchers proposed that the presence of $\mathrm{NO}_{\mathrm{x}}$ in the polar troposphere above a certain mixing ratio promotes the formation of ozone [42,43]. However, Cao et al. [44] studied the relationship between halogen release and ozone depletion by using a box model. They found that when the initial concentration of $\mathrm{NO}_{\mathrm{x}}$ in the Arctic troposphere is less than $15 \mathrm{ppt}$, the presence of $\mathrm{NO}_{\mathrm{x}}$ has a positive correlation with ozone depletion, which is influenced by the absorption coefficient of $\mathrm{BrONO}_{2}$ hydrolysis. It means that an enhancement of the nitrogen oxides in a low- $\mathrm{NO}_{\mathrm{x}}$ situation would cause a speed-up of the ODEs [44]. In contrast to that, Custard et al. [45] made simulations with two different $\mathrm{NO}_{\mathrm{x}}$ concentration ranges, representing cleaning conditions (50-100 ppt $\mathrm{NO}_{\mathrm{x}}$ ) and pollution conditions ( $700-1600 \mathrm{ppt} \mathrm{NO}_{\mathrm{x}}$ ), respectively. Their modeling results suggest that high concentrations of $\mathrm{NO}_{\mathrm{x}}$ may delay ozone depletion. They explained that, on one hand, $\mathrm{NO}_{\mathrm{x}}$ participation would terminate the halogen radical chain reaction, which would prohibit the ozone destruction. On the other hand, the process can also lead to the formation of bromine explosion products and thus the advancement of ODEs. The relative importance of these two mechanisms depends on the sensitivities of the related reactions to $\mathrm{NO}_{x}$ and the rate of each reaction.

Therefore, in this study, the role of nitrogen oxides in ODEs during the springtime of the Arctic is further investigated by using a box model. We applied a concentration sensitivity analysis to investigate how the nitrogen oxides influence the evolution of ozone during ODEs and explore the controversial role of nitrogen oxides in the halogen cycle.

\section{Mathematical Model and Methods}

In the present study, a box model developed by Cao et al. [44] was adopted. In this model, a halogen-related chemical mechanism was implemented into a software KINAL (KInetic aNALysis of reaction mechanics [46]). Moreover, a strictly defined air composition was used as the initial condition of the model. Then a following concentration sensitivity analysis was performed on the chemical mechanism.

In the chemical reaction mechanism (141 reactions and 49 species) used in this study, the initial air composition used in the model represents a typical Arctic atmosphere (see Table 1) [44], including a small amount of bromine and chlorine substances to trigger the bromine explosion mechanism. Compounds released from the underlying surface such as $\mathrm{NO}_{x}, \mathrm{HONO}$ and $\mathrm{HCHO}$ are also included (Table 2) [47-50]. The temporal variation of the species concentration is conveyed as follows:

$$
\frac{d c_{i}}{d t}=f\left(c_{i}, k_{j}\right)+E_{i}
$$

where $c_{i}$ denotes the concentration of the $i$-th species with the initial value of $c_{0} . k_{j}$ in Equation (1) represents the rate constant of the $j$-th reaction, and $t$ denotes time. $E_{i}$ is the emission rate of the $i$-th species from the underlying surface. In Equation (1), the term in the left side denotes the concentration change with time, and the right items represent the chemical production/consumption and the emission, respectively. Thus, the temporal evolution of species is determined by the net effect of chemical reactions and the local emissions from the surface. By solving the stiff ordinary differential Equation (1) using KINAL [46], the temporal evolution of ozone, principal bromine containing species and nitrogen related substances in the ODEs can be obtained. The reaction rate constants of gas-phase reactions are calculated based on the Arrhenius equation, assuming a constant temperature of 258K [18], 
which represents a typical Arctic temperature. A listing of all the reactions and the rate constants is given in the Appendix A.

Table 1. Initial atmospheric composition used in the present model study, adopted from Cao et al. [44] (ppm = part per million, $\left.10^{-6} \mathrm{~mol} / \mathrm{mol}\right)$.

\begin{tabular}{cccc}
\hline Species & Mixing Ratio & Species & Mixing Ratio \\
\hline $\mathrm{O}_{3}$ & $40 \mathrm{ppb}$ & $\mathrm{C}_{2} \mathrm{H}_{2}$ & $0.6 \mathrm{ppb}$ \\
$\mathrm{H}_{2} \mathrm{O}$ & $800 \mathrm{ppm}$ & $\mathrm{C}_{3} \mathrm{H}_{8}$ & $1.2 \mathrm{ppb}$ \\
$\mathrm{CO}$ & $132 \mathrm{ppb}$ & $\mathrm{NO}$ & $5 \mathrm{ppt}$ \\
$\mathrm{CO}_{2}$ & $371 \mathrm{ppm}$ & $\mathrm{NO}_{2}$ & $10 \mathrm{ppt}$ \\
$\mathrm{CH}_{4}$ & $1.9 \mathrm{ppm}$ & $\mathrm{Br}_{2}$ & $0.3 \mathrm{ppt}$ \\
$\mathrm{HCHO}$ & $0.1 \mathrm{ppb}$ & $\mathrm{HBr}$ & $0.01 \mathrm{ppt}$ \\
$\mathrm{CH}_{3} \mathrm{CHO}$ & $0.1 \mathrm{ppb}$ & $\mathrm{Cl}_{2}$ & $0.3 \mathrm{ppt}$ \\
$\mathrm{C}_{2} \mathrm{H}_{6}$ & $2.5 \mathrm{ppb}$ & $\mathrm{HCl}$ & $0.01 \mathrm{ppt}$ \\
$\mathrm{C}_{2} \mathrm{H}_{4}$ & $0.1 \mathrm{ppb}$ & & \\
\hline
\end{tabular}

Table 2. Emission fluxes from the ice/snow-covered ground surface, adopted from Cao et al. [44].

\begin{tabular}{ccc}
\hline Species & $\begin{array}{c}\text { Emission Rates } \\
\left(\text { molec. cm } \mathbf{~}^{-2} \cdot \mathbf{s}^{-\mathbf{1}}\right)\end{array}$ & Reference \\
\hline $\mathrm{NO}$ & $1.6 \times 10^{7}$ & Jones et al. [47], Jones et al. [48] \\
$\mathrm{NO}_{2}$ & $1.6 \times 10^{7}$ & Jones et al. [47], Jones et al. [48] \\
$\mathrm{HONO}$ & $1.6 \times 10^{7}$ & Grannas et al. [49] \\
$\mathrm{H}_{2} \mathrm{O}_{2}$ & $1.0 \times 10^{8}$ & Jacobi et al. [50] \\
$\mathrm{HCHO}$ & $6.0 \times 10^{7}$ & Jacobi et al. [50] \\
\hline
\end{tabular}

Apart from the gas-phase reactions discussed above, during the ODEs, there are several multiphase reactions occurring on the surface of the substrates including the suspended aerosols and the ice-/snow-covered surfaces. The estimation of the heterogeneous reaction rates is associated with the properties of the suspended aerosols in the atmosphere and the local meteorological conditions such as the stability of the boundary layer and the wind speed [51]. For the heterogeneous reactions occurring in the aerosols, the reaction rate constant can be expressed as [52]:

$$
\begin{gathered}
k_{\text {aerosol }}=\left(\frac{r}{D_{g}}+\frac{4}{V_{\text {therm }} \gamma}\right)^{-1} \alpha_{\text {eff }} \\
\alpha_{\text {eff }}=V_{\text {aerosol }} \cdot 3 / r
\end{gathered}
$$

where $r$ is the typical aerosol radius in polar conditions and is estimated as $0.3 \mu \mathrm{m}$ in this model. $D_{g}$ in Equation (2) denotes the diffusivity of gas-phase molecules and here it values $0.2 \mathrm{~cm}^{2} \cdot \mathrm{s}^{-1}$, $V_{\text {therm }}$ represents the average speed of molecular thermal motion. $\gamma$ means the uptake coefficient of $\mathrm{HOBr}$ or $\mathrm{BrONO}_{2}$ for the heterogeneous reactions occurring on the surface of aerosols. For $\mathrm{BrONO}_{2}$, $\gamma$ in Equation (2) takes 0.06 [53], while for the uptake of $\mathrm{HOBr}$ in the acidic condition, the value of $\gamma$ is estimated according to the approach of Hanson et al. [54]. The item $\alpha_{\text {eff }}$ in Equation (2) denotes the surface area density of the suspended aerosols. $V_{\text {aerosol }}$ represents the aerosol volume density, and under the condition of Arctic region in springtime it takes $10^{-5} \mathrm{~cm}^{3} \cdot \mathrm{s}^{-3}$ as a typical value. Thus, the surface area density for aerosols $\alpha_{\text {eff }}$ is calculated as $10^{-4} \mathrm{~m}^{-1}$ [55].

The parameterization scheme for the heterogeneous reactions occurring on ice or snow refers to previous model studies [18,44,51], in which the wind speed is set to $8 \mathrm{~m} \cdot \mathrm{s}^{-1}$ [56] and the roughness of the reaction surface is assumed as $10^{-5} \mathrm{~m}$ [57]. The uptake coefficient $\gamma$ for the heterogeneous reactions of $\mathrm{HOBr}$ and $\mathrm{BrONO}_{2}$ on the ice or snow surface is assumed as 0.06 [53]. Besides, the height of the boundary layer and the surface layer are assumed as $200 \mathrm{~m}$ and $20 \mathrm{~m}$, respectively for the typical height observed in springtime of Arctic [56]. 
In order to investigate the role of nitrogen oxides in the ODEs, different initial values of $\mathrm{NO}_{x}$ (from $3 \mathrm{ppt}$ to $450 \mathrm{ppt}$ ) were tested in the present study. When the value of $\mathrm{NO}_{\mathrm{x}}$ concentration was modified, the model outputs the corresponding temporal change of ozone and principal bromine species for comparison.

Afterward, we performed a concentration sensitivity analysis on the present reaction mechanism to identify the relative importance of each component in the initial air composition during ODEs by showing the concentration sensitivity

$$
\tilde{S}_{\mathrm{ij}}(t)=\frac{\partial\left(\ln C_{i}(t)\right)}{\partial\left(\ln C_{j}^{0}\right)}=\frac{C_{j}^{0}}{C_{i}(t)} \cdot \frac{\partial\left(C_{i}(t)\right)}{\partial C_{j}^{0}} .
$$

The sensitivity coefficient $\tilde{S}_{\mathrm{ij}}$ is a dimensionless parameter representing the percentage change of the $i$-th species concentration due to 1 percent variation of the $j$-th species. $C_{i}(t)$ is the concentration of the $i$-th chemical species at the time $t$, and $C_{j}^{0}$ denotes the initial concentration of the $j$-th species. The relative concentration sensitivity is computed in KINAL by using a Decomposed Direct Method [58], which has been proven robust and highly efficient [59].

\section{Results and Discussion}

In this section, we first show the temporal evolution of the principal chemical species such as ozone, bromine species and nitrogen oxides in the $200 \mathrm{~m}$ boundary layer during the ODEs. Then, the evolution of ozone and principal bromine species with different initial $\mathrm{NO}_{\mathrm{x}}$ concentrations is presented. At last, the relative concentration sensitivities of ozone to the initial air composition under different initial $\mathrm{NO}_{\mathrm{x}}$ conditions are given and discussed.

\subsection{Temporal Evolution of Ozone and Principal Bromine Species}

Figure 1 shows the temporal evolution of ozone and principal bromine containing species. It can be seen that before day 3, ozone is hardly consumed and maintains the background level of about $40 \mathrm{ppb}$, and the average depletion rate during these 3 days is about $0.01 \mathrm{ppbv} \cdot \mathrm{h}^{-1}$. After day 3 , ozone begins to deplete rapidly and decreases below $0.05 \mathrm{ppb}$ within two days. At the same time, both the mixing ratios of $\mathrm{BrO}$ and $\mathrm{HOBr}$ increase exponentially. They construct the major bromine amount in this period, reaching a peak value of $50 \mathrm{ppt}$ and $30 \mathrm{ppt}$, respectively. These values are in consistence with the findings of Liao et al. [60], who reported an average value of $\mathrm{BrO}$ within a range of 20-60 ppt and $\mathrm{HOBr}$ approximately 20-30 ppt during ODEs. When the ozone is consumed completely, $\mathrm{BrO}$ and $\mathrm{HOBr}$ decrease sharply to near-zero values, while atomic $\mathrm{Br}$ begins to accumulate in the atmosphere from day 5 and then reaches a maximum value of about $80 \mathrm{ppt}$. In the last period, bromine is nearly entirely converted to $\mathrm{HBr}$ by the absorption of aldehydes such as $\mathrm{HCHO}$ and $\mathrm{CH}_{3} \mathrm{CHO}$ in the atmosphere, which has been confirmed by the measurements of Langendörfer et al. [61].

\subsection{Temporal Evolution of Nitrogen Oxides}

We also show the evolution of nitrogen containing species during ODEs in Figure 2. It is seen that the concentrations of $\mathrm{NO}$ and $\mathrm{NO}_{2}$ drop sharply in the first two days, while $\mathrm{HNO}_{3}, \mathrm{HONO}$ and PAN (peroxyacetyl nitrate) increase steadily in the simulated ten days due to the conversions:

$$
\begin{gathered}
\mathrm{NO}_{2}+\mathrm{HO} \rightarrow \mathrm{HNO}_{3}, \\
\mathrm{NO}+\mathrm{HO} \rightarrow \mathrm{HONO}, \\
\mathrm{NO}_{2}+\mathrm{CH}_{3} \mathrm{CO}_{3} \rightarrow \mathrm{PAN} .
\end{gathered}
$$

This enhancement of PAN during the ODEs was also observed by Bottenheim et al. [16] in measurements conducted at Alert, Canada, for nitrogen containing compounds. 


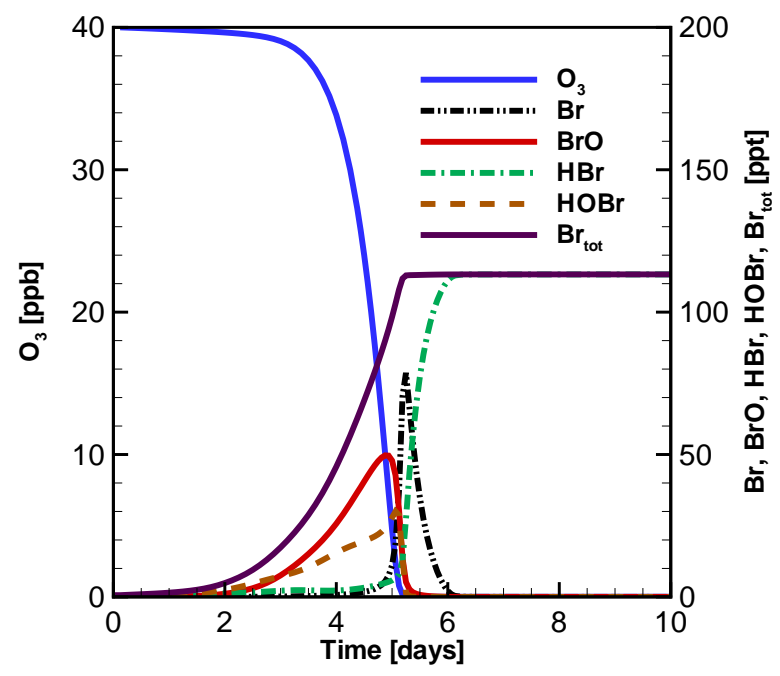

Figure 1. The development of the mixing ratios of ozone and principal bromine species with time in a $200 \mathrm{~m}$ boundary layer.

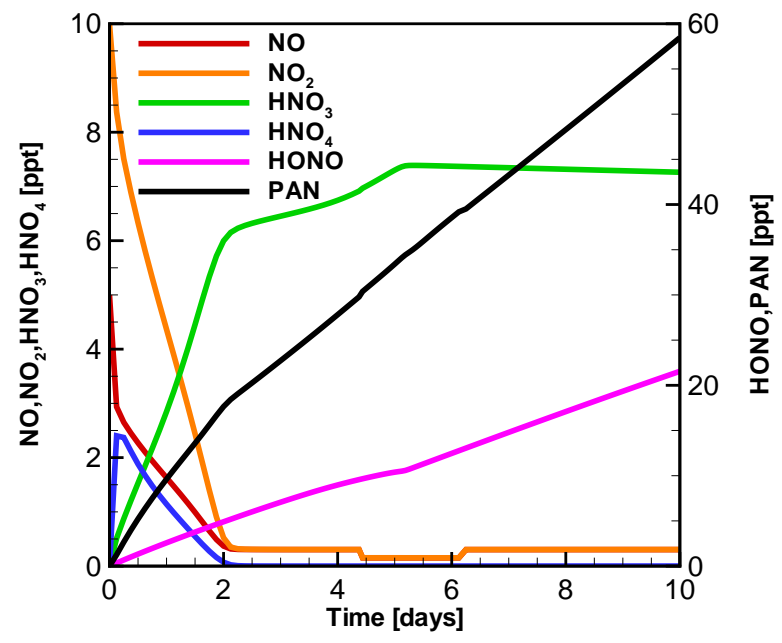

Figure 2. The evolution of nitrogen species under the initial $\mathrm{NO}_{\mathrm{x}}$ of $15 \mathrm{ppt}$.

It is also interesting to note that the concentration of $\mathrm{HNO}_{4}$ peaks at the beginning of the reaction, then drops to a near-zero value in two days and remains a low value until the end of the ozone depletion simulation. This is because that at the beginning of the simulation, $\mathrm{HNO}_{4}$ is generated by

$$
\mathrm{NO}_{2}+\mathrm{HO}_{2} \rightarrow \mathrm{HNO}_{4}
$$

and then quickly decomposed via reactions:

$$
\begin{aligned}
& \mathrm{HNO}_{4}(+\mathrm{M}) \rightarrow \mathrm{NO}_{2}+\mathrm{HO}_{2}(+\mathrm{M}), \\
& \mathrm{HNO}_{4}+\mathrm{OH} \rightarrow \mathrm{NO}_{2}+\mathrm{HO}_{2}(+\mathrm{M}) .
\end{aligned}
$$

\subsection{Influence of the $\mathrm{NO}_{x}$ Initial Concentration}

To investigate the influence might be caused by the change of the initial concentration of $\mathrm{NO}_{\mathrm{x}}$ on the ODEs, we varied the initial amount of $\mathrm{NO}_{\mathrm{x}}$ from 3 ppt to 450 ppt. Figure 3 shows the evolution of ozone with different initial $\mathrm{NO}_{\mathrm{x}}$ concentrations. 


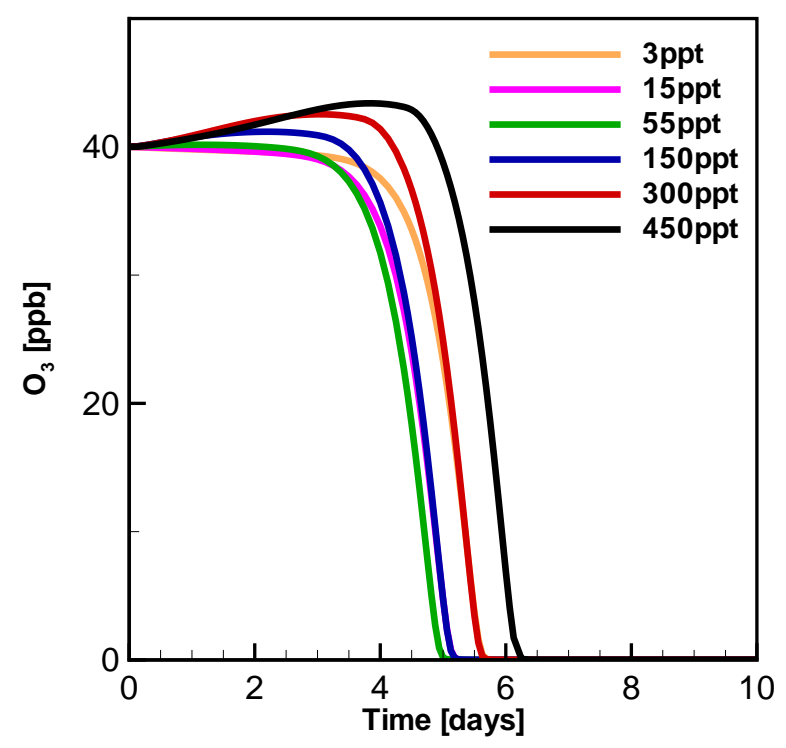

Figure 3. Depletion of ozone under different initial concentrations of $\mathrm{NO}_{\mathrm{x}}$.

It is shown that when the initial concentration of $\mathrm{NO}_{\mathrm{x}}$ increases from $3 \mathrm{ppt}$ to around $55 \mathrm{ppt}$, the onset of ozone depletion is advanced. However, when the initial $\mathrm{NO}_{\mathrm{x}}$ reaches approximately $55 \mathrm{ppt}$, the existence of the nitrogen oxides exerts a minor influence on the occurrence of ODEs. After that, when the initial $\mathrm{NO}_{\mathrm{x}}$ keeps increasing, the onset of the ozone depletion is retarded. It is seen the ozone depletion rate in the $150 \mathrm{ppt} \mathrm{NO}_{\mathrm{x}}$ simulation is nearly identical to that in the $15 \mathrm{ppt} \mathrm{NO}_{\mathrm{x}}$ case, and the $300 \mathrm{ppt}$ case is similar to the $3 \mathrm{ppt}$ case. It indicates that when the initial $\mathrm{NO}_{\mathrm{x}}$ concentration exceeds a critical value (i.e., about $55 \mathrm{ppt}$ in this study), a higher $\mathrm{NO}_{\mathrm{x}}$ initial value tends to retard the ODEs. It is also interesting to note that, under the situations of the initial $150 \mathrm{ppt}, 300 \mathrm{ppt}$ and $450 \mathrm{ppt}$ $\mathrm{NO}_{x}$, during the beginning period of ODEs (i.e., the ozone depletion rate is less than $0.1 \mathrm{ppb} \mathrm{h}^{-1}$ [44]), the amount of ozone even increases. This is caused by the high background level of $\mathrm{NO}_{\mathrm{x}^{\prime}}$ leading to a rapid ozone formation before the consumption caused by bromine.

Figure 4 shows the evolution of $\mathrm{Br}$ and $\mathrm{BrO}$ under the situations of the initial $\mathrm{NO}_{\mathrm{x}}$ of $15 \mathrm{ppt}$, $55 \mathrm{ppt}$ and $150 \mathrm{ppt}$, respectively, representing the $\mathrm{NO}_{\mathrm{x}}$ concentration with low, middle and high initial values. By doing that, we can observe the influence of the initial concentration of $\mathrm{NO}_{\mathrm{x}}$ on the bromine-containing compounds during the ozone depletion. It is seen in Figure 4 that the increase of the initial concentration of $\mathrm{NO}_{\mathrm{x}}$ from $15 \mathrm{ppt}$ to $55 \mathrm{ppt}$ promotes the occurrence of the bromine explosion and thus enhances the rate of ozone depletion. Conversely, when $\mathrm{NO}_{\mathrm{x}}$ concentration increases from $55 \mathrm{ppt}$ to $150 \mathrm{ppt}$, the production of bromine species is delayed, thus reducing the ozone depletion rate. However, the change in the $\mathrm{NO}_{\mathrm{x}}$ initial concentration has no significant impact on the peak value of bromine species.

Our findings can be compared with those of Tas et al. [62]. In their study, based on extensive field measurements [63] performed in the Dead Sea area and a box model simulation, Tas et al. [62] investigated the connection between the level of $\mathrm{NO}_{2}$ and the activity of reactive bromine species during the destruction of ozone. They found that the anthropogenic emission of nitrogen oxides may cause an enhancement of the bromine activity under a low nitrogen condition. However, if the level of $\mathrm{NO}_{2}$ exceeds a certain threshold, a further increase in the $\mathrm{NO}_{2}$ concentration leads to a decrease of the bromine concentration. Because the destruction of ozone in the Dead Sea area investigated by Tas et al. [62] is also caused by the bromine related chemistry, which is similar to ODEs, considering the negative dependence of the ozone mixing ratio on the bromine species, the findings of our study are qualitatively in agreement with those of Tas et al. [62]. 


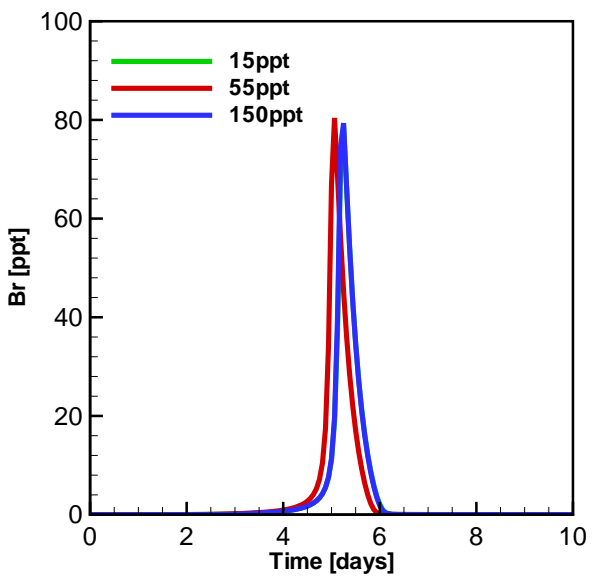

(a) $\mathrm{Br}$

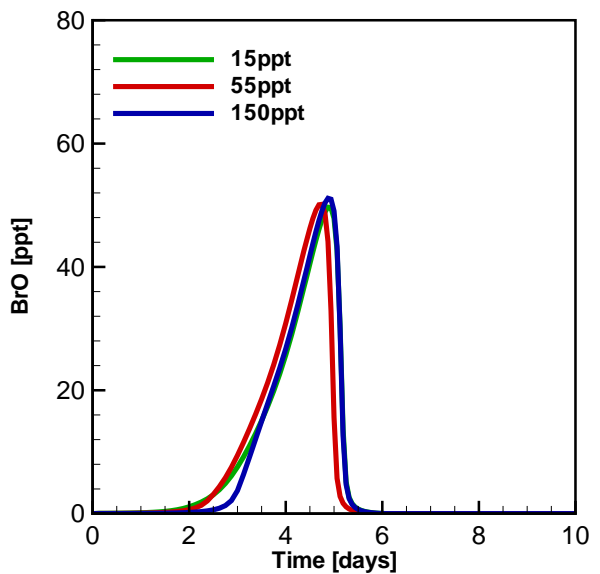

(b) $\mathrm{BrO}$

Figure 4. The evolution of (a) $\mathrm{Br}$ and (b) $\mathrm{BrO}$ under an initial $\mathrm{NO}_{\mathrm{x}}$ of $15 \mathrm{ppt}$ (green curve), $55 \mathrm{ppt}$ (red curve) and 150 ppt (blue curve).

\subsection{Concentration Sensitivity Analysis of Ozone and Bromine Containing Compounds during the ODEs}

In this section, a concentration sensitivity analysis is applied on the present reaction mechanism for the time period during the ODEs. Figure 5 displays the relative concentration sensitivities of ozone on day 4.5 (noon of the fourth day), which resides in the most intense period of the ozone depletion under the situation of a $15 \mathrm{ppt}$ initial $\mathrm{NO}_{\mathrm{x}}$. It is seen that for the ozone mixing ratio, the sign of the sensitivity coefficient corresponding to the initial nitrogen oxide is negative. This means that an increase of the initial concentration of $\mathrm{NO}_{\mathrm{x}}$ would reduce the ozone mixing ratio during ODEs in the case of $15 \mathrm{ppt}$. As a result, the depletion is promoted due to the increase of the initial $\mathrm{NO}_{\mathrm{x}}$. This is mainly due to the hydrolysis of $\mathrm{BrONO}_{2}$ via (R11), which increases the production of $\mathrm{HOBr}$ by (R10), leading to a further ozone depletion through the heterogeneous bromide activation:

$$
\begin{gathered}
\mathrm{BrO}+\mathrm{NO}_{2} \rightarrow \mathrm{BrONO}_{2}, \\
\mathrm{BrONO}_{2}+\mathrm{H}_{2} \mathrm{O} \rightarrow \mathrm{HOBr}+\mathrm{HNO}_{3} .
\end{gathered}
$$

For situations with an initial $\mathrm{NO}_{\mathrm{x}}$ concentration of $55 \mathrm{ppt}$ and $150 \mathrm{ppt}$, the relative concentration sensitivities of ozone are displayed in Figures 6 and 7, respectively. Compared to the results shown in Figure 5, the sensitivity coefficients of ozone corresponding to the initial nitrogen oxides are close to zero in the case of $55 \mathrm{ppt}$, while in the case of $150 \mathrm{ppt}$ they are positive. It can be concluded that, for different initial nitrogen oxide concentrations, $\mathrm{NO}_{\mathrm{x}}$ concentration has different impacts on ozone depletion. With a low background level of $\mathrm{NO}_{\mathrm{x}}$, the increase of $\mathrm{NO}_{\mathrm{x}}$ can promote the ozone depletion. On the contrary, with higher level of $\mathrm{NO}_{\mathrm{x}}$, the existence of $\mathrm{NO}_{\mathrm{x}}$ will prohibit the ozone depletion. This is attributed to the formation of ozone through the reaction cycle between VOCs and $\mathrm{NO}_{x}$ with the presence of sunlight:

$$
\begin{gathered}
\mathrm{OH}+\mathrm{RH}+\mathrm{O}_{2} \rightarrow \mathrm{RO}_{2}+\mathrm{H}_{2} \mathrm{O}, \\
\mathrm{RO}_{2}+\mathrm{NO} \rightarrow \mathrm{RO}+\mathrm{NO}_{2}, \\
\mathrm{NO}_{2}+\mathrm{h} v \rightarrow \mathrm{NO}+\mathrm{O}, \\
\mathrm{O}+\mathrm{O}_{2}(+\mathrm{M}) \rightarrow \mathrm{O}_{3}(+\mathrm{M}), \\
\mathrm{Net}: \mathrm{OH}+\mathrm{RH}+2 \mathrm{O}_{2}(+\mathrm{M}) \rightarrow \mathrm{RO}+\mathrm{O}_{3}+\mathrm{H}_{2} \mathrm{O}(+\mathrm{M}) .
\end{gathered}
$$




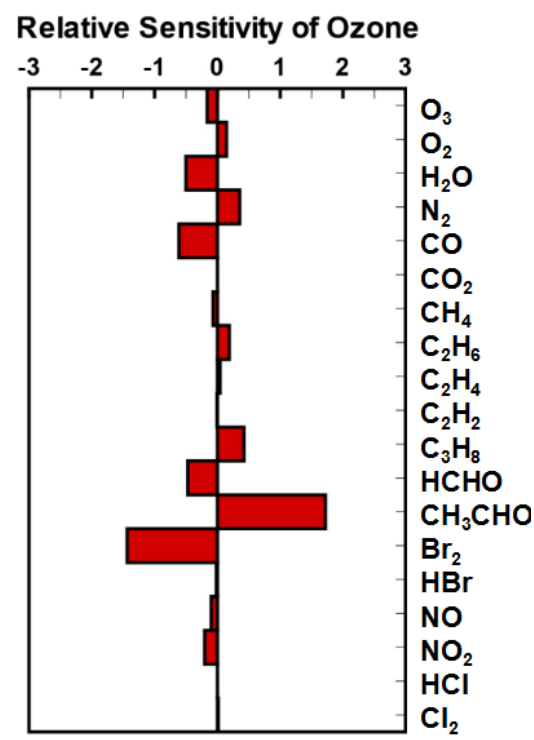

Figure 5. Relative concentration sensitivities of ozone under an initial $\mathrm{NO}_{\mathrm{x}}$ of $15 \mathrm{ppt}$ on day 4.5.

By analogy to $\mathrm{CH}_{4}$, reaction of $\mathrm{OH}$ with many hydrocarbons (RH) leads to the formation of alkyl peroxy radicals $\left(\mathrm{RO}_{2}\right)$ through (R19). The formed alkyl peroxy radicals are able to oxidize $\mathrm{NO}$ to $\mathrm{NO}_{2}$, which is able to compensate ozone through the following photolysis of NO.

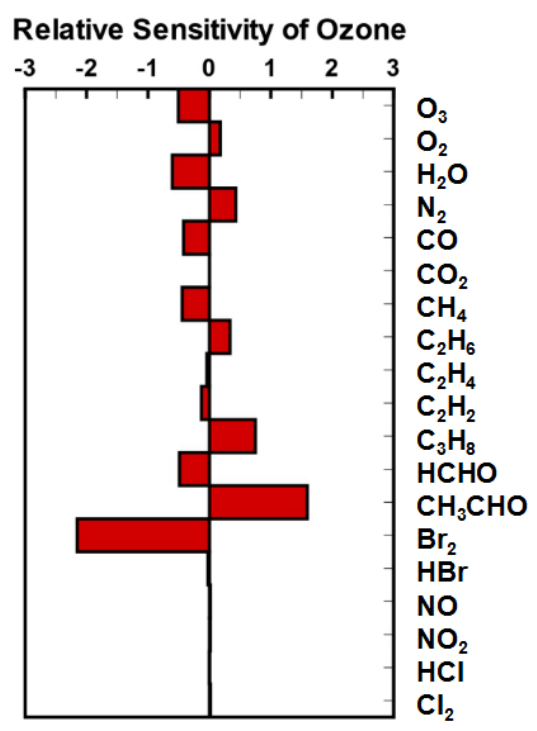

Figure 6. Relative concentration sensitivities of ozone under an initial $\mathrm{NO}_{\mathrm{x}}$ of $55 \mathrm{ppt}$ on day 4.5.

Figure 8 compares the time variation of the relative concentration sensitivities of ozone to the initial $\mathrm{NO}_{x}$ under different initial $\mathrm{NO}_{\mathrm{x}}$ amounts. It can be seen that in the case of 55 ppt initial $\mathrm{NO}_{x}$, the sensitivity coefficients of ozone to the initial nitrogen oxides are nearly identical to zero. Thus, a critical value of the $\mathrm{NO}_{\mathrm{x}}$ background level exists, with which the ozone depletion rate is independent of the initial value of $\mathrm{NO}_{\mathrm{x}}$, and the critical value is found approximated 55 ppt in the present study. 


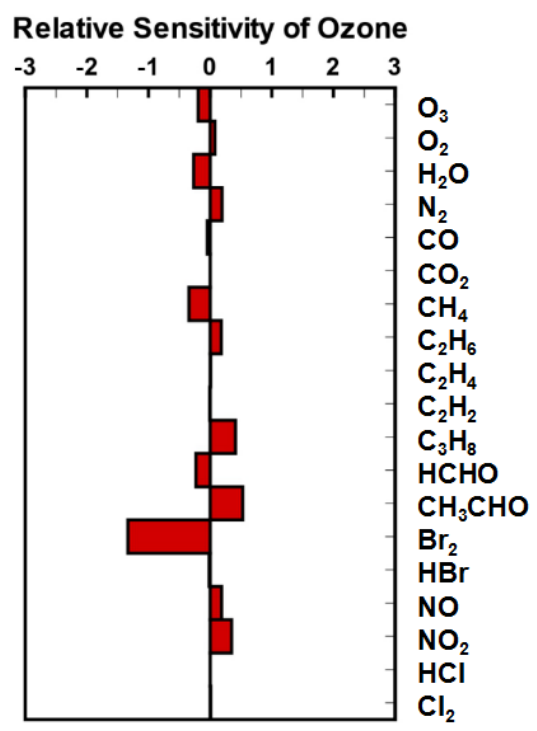

Figure 7. Relative concentration sensitivities of ozone under an initial $\mathrm{NO}_{\mathrm{x}}$ of $150 \mathrm{ppt}$ on day 4.5 .

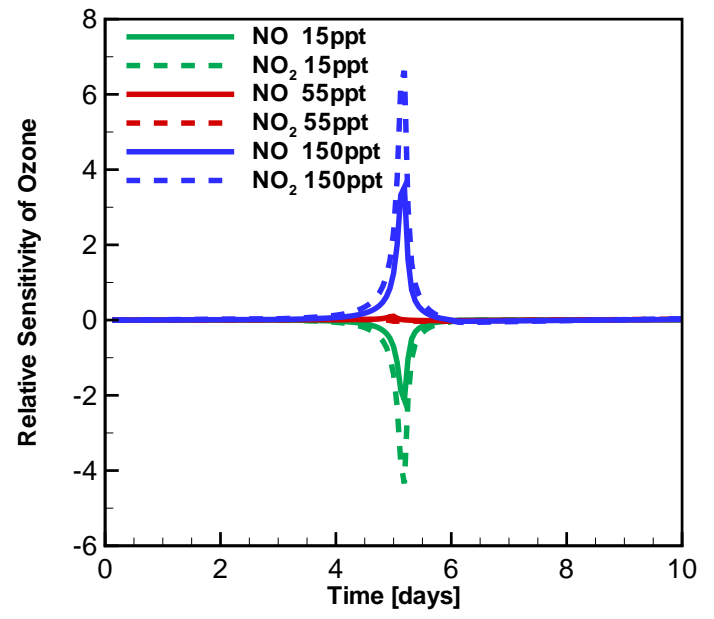

Figure 8. Temporal change of the relative concentration sensitivities of ozone to the initial NO (solid) and $\mathrm{NO}_{2}$ (dashed) under an initial $\mathrm{NO}_{\mathrm{x}}$ of $15 \mathrm{ppt}$ (green curve), $55 \mathrm{ppt}$ (red curve) and $150 \mathrm{ppt}$ (blue curve).

\section{Conclusions and Future Work}

In this study, the role of $\mathrm{NO}_{\mathrm{x}}$ in ODEs during springtime in the Arctic was further investigated systematically through a model study by implementing a sensitivity analysis. The timescale of the ozone depletion, as well as the temporal evolution of ozone and bromine containing compounds in the presence of different initial $\mathrm{NO}_{\mathrm{x}}$, were also analyzed.

It was found in the present study that when the initial concentration of $\mathrm{NO}_{\mathrm{x}}$ in the Arctic troposphere is less than $55 \mathrm{ppt}$, the increase of the $\mathrm{NO}_{\mathrm{x}}$ background level apparently strengthens the consumption of ozone and the enhancement of halogen. In addition, the onset of the ozone depletion is also advanced. In contrast to that, when the initial $\mathrm{NO}_{\mathrm{x}}$ concentration is higher than $55 \mathrm{ppt}$, the ODEs are retarded and the delayed time positively depends on the initial $\mathrm{NO}_{\mathrm{x}}$ concentration.

The concentration sensitivity analysis also confirms the role of $\mathrm{NO}_{\mathrm{x}}$ in the ODEs in different scenarios. With a relatively low background level of $\mathrm{NO}_{x}$, the sensitivity of ozone to the initial $\mathrm{NO}_{\mathrm{x}}$ keeps positive, denoting a positive correlation of the ozone concentration with the initial $\mathrm{NO}_{\mathrm{x}}$ value during ODEs. In contrast to that, with a high background level of $\mathrm{NO}_{\mathrm{x}}$, ozone possesses a negative sensitivity to the initial $\mathrm{NO}_{\mathrm{x}}$, representing a delay of ODEs caused by the increase of the initial $\mathrm{NO}_{\mathrm{x}}$. 
The critical value of the $\mathrm{NO}_{\mathrm{x}}$ initial concentration separating these two situations was found to be approximately $55 \mathrm{ppt}$.

The present study still has a few deficiencies to be improved. In terms of the model, the temporal and the spatial variations of the emissions from underlying surface are not taken into account, while the emission rates of the species such as $\mathrm{HONO}$ and $\mathrm{NO}_{\mathrm{x}}$ from the underlying ice-/snow-covered surface should vary during the daytime and nighttime. It would also be beneficial to extend the model to other conditions by modifying the values of the meteorological parameters, such as the wind speed and the temperature, because the variation of these factors alters the chemical reaction rates, which might influence the importance of each reaction in the ODEs as well as the critical turning value of the initial $\mathrm{NO}_{\mathrm{x}}$ obtained in the present study. In addition, the diurnal variation of the photolysis reactions was not considered in the present study. It is also of great significance to improve the present model by making a comparison with observational data. The research in the future will not only be restricted to Arctic regions, it could also be extended to other related issues such as the regional ozone pollution episodes.

Author Contributions: L.C. conceived and designed the simulation scenarios. L.C. and J.Z. performed the computations and wrote the paper. S.L. participated in the analysis of the the chemical reaction mechanism and gave valuable suggestions. All authors have read and agreed to the published version of the manuscript.

Funding: This work was financially supported by the National Natural Science Foundation of China (No. 41375044), the Natural Science Foundation of Jiangsu Province (No. 2015s042) and the Double Innovation Talent Program (No. R2015SCB02).

Acknowledgments: The authors like to thank Liting Liu in School of Atmospheric Physics, NUIST for her fundamental work on this topic. We also wish to thank three anonymous reviewers and the editor for their perspicacious comments that significantly improved our paper.

Conflicts of Interest: The authors declare no conflict of interest.

\section{Appendix A}

Table A1. The complete list of chemical reactions used in a present study, a constant temperature $T=258 \mathrm{~K}$ is implemented, and the rate of third-body reactions is estimated as $k=k_{\infty} \times \frac{k_{0} / k_{\infty}}{\left(1+k_{0} / k_{\infty}\right)} \times$ $F_{C}^{\frac{1}{1+\left(\log _{10}\left(k_{0} / k_{\infty}\right)\right)^{2}}}[64]$.

\begin{tabular}{|c|c|c|c|}
\hline $\begin{array}{l}\text { Reaction } \\
\text { Number }\end{array}$ & Reaction & $\begin{array}{l}k \\
{\left[\left(\text { molec. } \mathbf{c m}^{-3}\right)^{1-n} \mathbf{s}^{-1}\right]}\end{array}$ & Reference \\
\hline (R1) & $\mathrm{O}_{3}+\mathrm{h} v \rightarrow \mathrm{O}\left({ }^{1} \mathrm{D}\right)+\mathrm{O}_{2}$ & $4.70 \times 10^{-7}$ & Lehrer et al. [18] \\
\hline (R2) & $\mathrm{O}\left({ }^{1} \mathrm{D}\right)+\mathrm{O}_{2} \rightarrow \mathrm{O}_{3}$ & $4.15 \times 10^{-11}$ & Atkinson et al. [64] \\
\hline (R3) & $\mathrm{O}\left({ }^{1} \mathrm{D}\right)+\mathrm{N}_{2} \rightarrow \mathrm{O}_{3}+\mathrm{N}_{2}$ & $2.73 \times 10^{-11}$ & Atkinson et al. [64] \\
\hline (R4) & $\mathrm{O}\left({ }^{1} \mathrm{D}\right)+\mathrm{H}_{2} \mathrm{O} \rightarrow 2 \mathrm{OH}$ & $2.20 \times 10^{-10}$ & Atkinson et al. [64] \\
\hline (R5) & $\mathrm{Br}+\mathrm{O}_{3} \rightarrow \mathrm{BrO}+\mathrm{O}_{2}$ & $7.65 \times 10^{-13}$ & Atkinson et al. [64] \\
\hline (R6) & $\mathrm{Br}_{2}+\mathrm{h} v \rightarrow 2 \mathrm{Br}$ & $2.10 \times 10^{-2}$ & Lehrer et al. [18] \\
\hline (R7) & $\mathrm{BrO}+\mathrm{h} v \stackrel{\mathrm{O}_{2}}{\longrightarrow} \mathrm{Br}+\mathrm{O}_{3}$ & $1.40 \times 10^{-2}$ & Lehrer et al. [18] \\
\hline (R8) & $\mathrm{BrO}+\mathrm{BrO} \rightarrow 2 \mathrm{Br}+\mathrm{O}_{2}$ & $2.70 \times 10^{-12}$ & Atkinson et al. [64] \\
\hline (R9) & $\mathrm{BrO}+\mathrm{BrO} \rightarrow \mathrm{Br}_{2}+\mathrm{O}_{2}$ & $7.52 \times 10^{-13}$ & Atkinson et al. [64] \\
\hline (R10) & $\mathrm{BrO}+\mathrm{HO}_{2} \rightarrow \mathrm{HOBr}+\mathrm{O}_{2}$ & $3.13 \times 10^{-11}$ & Atkinson et al. [64] \\
\hline (R11) & $\mathrm{HOBr}+\mathrm{h} v \rightarrow \mathrm{Br}+\mathrm{OH}$ & $3.00 \times 10^{-4}$ & Lehrer et al. [18] \\
\hline (R12) & $\mathrm{CO}+\mathrm{OH}(+\mathrm{M}) \stackrel{\mathrm{O}_{2}}{\longrightarrow} \mathrm{HO}_{2}+\mathrm{CO}_{2}(+\mathrm{M})$ & $2.25 \times 10^{-13}$ & Atkinson et al. [64] \\
\hline (R13) & $\mathrm{Br}+\mathrm{HO}_{2} \rightarrow \mathrm{HBr}+\mathrm{O}_{2}$ & $1.35 \times 10^{-12}$ & Atkinson et al. [64] \\
\hline (R14) & $\mathrm{HOBr}+\mathrm{HBr} \stackrel{\text { aerosol }}{\longrightarrow} \mathrm{Br}_{2}+\mathrm{H}_{2} \mathrm{O}$ & $2.05 \times 10^{-12}$ & Cao et al. [44] \\
\hline (R15) & $\mathrm{HOBr}+\mathrm{H}^{+}+\mathrm{Br}^{-} \stackrel{\text { ice }}{\longrightarrow} \mathrm{Br}_{2}+\mathrm{H}_{2} \mathrm{O}$ & $3.03 \times 10^{-5}$ & Cao et al. [44] \\
\hline (R16) & $\mathrm{Br}+\mathrm{HCHO} \stackrel{\mathrm{O}_{2}}{\longrightarrow} \mathrm{HBr}+\mathrm{CO}+\mathrm{HO}_{2}$ & $7.65 \times 10^{-13}$ & Lehrer et al. [18] \\
\hline (R17) & $\mathrm{Br}+\mathrm{CH}_{3} \mathrm{CHO} \stackrel{\mathrm{O}_{2}}{\longrightarrow} \mathrm{HBr}+\mathrm{CH}_{3} \mathrm{CO}_{3}$ & $3.03 \times 10^{-12}$ & Atkinson et al. [64] \\
\hline
\end{tabular}


Table A1. Cont.

\begin{tabular}{|c|c|c|c|}
\hline $\begin{array}{l}\text { Reaction } \\
\text { Number }\end{array}$ & Reaction & $\begin{array}{l}k \\
{\left[\left(\text { molec. } \mathrm{cm}^{-3}\right)^{1-n} \mathrm{~s}^{-1}\right]}\end{array}$ & Reference \\
\hline (R18) & $\mathrm{Br}_{2}+\mathrm{OH} \rightarrow \mathrm{HOBr}+\mathrm{Br}$ & $5.07 \times 10^{-11}$ & Atkinson et al. [64] \\
\hline (R19) & $\mathrm{HBr}+\mathrm{OH} \rightarrow \mathrm{H}_{2} \mathrm{O}+\mathrm{Br}$ & $1.22 \times 10^{-11}$ & Atkinson et al. [64] \\
\hline (R20) & $\mathrm{Br}+\mathrm{C}_{2} \mathrm{H}_{2} \stackrel{3 \mathrm{O}_{2}}{\longrightarrow} 2 \mathrm{CO}+2 \mathrm{HO}_{2}+\mathrm{Br}$ & $4.20 \times 10^{-14}$ & Borken [65] \\
\hline$(\mathrm{R} 21)$ & $\mathrm{Br}+\mathrm{C}_{2} \mathrm{H}_{2} \stackrel{2 \mathrm{O}_{2}}{\longrightarrow} 2 \mathrm{CO}+\mathrm{HO}_{2}+\mathrm{HBr}$ & $8.92 \times 10^{-14}$ & Borken [65] \\
\hline (R22) & $\mathrm{Br}+\mathrm{C}_{2} \mathrm{H}_{4} \stackrel{3.5 \mathrm{O}_{2}}{\longrightarrow} 2 \mathrm{CO}+2 \mathrm{HO}_{2}+\mathrm{Br}+\mathrm{H}_{2} \mathrm{O}$ & $2.52 \times 10^{-13}$ & Barnes et al. [66] \\
\hline (R23) & $\mathrm{Br}+\mathrm{C}_{2} \mathrm{H}_{4} \stackrel{2.5 \mathrm{O}_{2}}{\longrightarrow} 2 \mathrm{CO}+\mathrm{HO}_{2}+\mathrm{HBr}+\mathrm{H}_{2} \mathrm{O}$ & $5.34 \times 10^{-13}$ & Barnes et al. [66] \\
\hline (R24) & $\mathrm{CH}_{4}+\mathrm{OH} \stackrel{\mathrm{O}_{2}}{\longrightarrow} \mathrm{CH}_{3} \mathrm{O}_{2}+\mathrm{H}_{2} \mathrm{O}$ & $2.64 \times 10^{-15}$ & Atkinson et al. [64] \\
\hline$(\mathrm{R} 25)$ & $\mathrm{BrO}+\mathrm{CH}_{3} \mathrm{O}_{2} \rightarrow \mathrm{Br}+\mathrm{HCHO}+\mathrm{HO}_{2}$ & $1.60 \times 10^{-12}$ & Aranda et al. [67] \\
\hline (R26) & $\mathrm{BrO}+\mathrm{CH}_{3} \mathrm{O}_{2} \rightarrow \mathrm{HOBr}+\mathrm{HCHO}+0.5 \mathrm{O}_{2}$ & $4.10 \times 10^{-12}$ & Aranda et al. [67] \\
\hline (R27) & $\mathrm{OH}+\mathrm{O}_{3} \rightarrow \mathrm{HO}_{2}+\mathrm{O}_{2}$ & $4.45 \times 10^{-14}$ & Atkinson et al. [64] \\
\hline (R28) & $\mathrm{OH}+\mathrm{HO}_{2} \rightarrow \mathrm{H}_{2} \mathrm{O}+\mathrm{O}_{2}$ & $1.26 \times 10^{-10}$ & Atkinson et al. [64] \\
\hline (R29) & $\mathrm{OH}+\mathrm{H}_{2} \mathrm{O}_{2} \rightarrow \mathrm{HO}_{2}+\mathrm{H}_{2} \mathrm{O}$ & $1.56 \times 10^{-12}$ & Atkinson et al. [64] \\
\hline (R30) & $\mathrm{OH}+\mathrm{OH} \stackrel{\mathrm{O}_{2}}{\longrightarrow} \mathrm{H}_{2} \mathrm{O}+\mathrm{O}_{3}$ & $1.66 \times 10^{-12}$ & Atkinson et al. [64] \\
\hline (R31) & $\mathrm{HO}_{2}+\mathrm{O}_{3} \rightarrow \mathrm{OH}+2 \mathrm{O}_{2}$ & $1.50 \times 10^{-15}$ & Atkinson et al. [64] \\
\hline (R32) & $\mathrm{HO}_{2}+\mathrm{HO}_{2} \rightarrow \mathrm{O}_{2}+\mathrm{H}_{2} \mathrm{O}_{2}$ & $2.25 \times 10^{-12}$ & Atkinson et al. [64] \\
\hline (R33) & $\mathrm{C}_{2} \mathrm{H}_{6}+\mathrm{OH} \rightarrow \mathrm{C}_{2} \mathrm{H}_{5}+\mathrm{H}_{2} \mathrm{O}$ & $1.43 \times 10^{-13}$ & Atkinson et al. [64] \\
\hline (R34) & $\mathrm{C}_{2} \mathrm{H}_{5}+\mathrm{O}_{2} \rightarrow \mathrm{C}_{2} \mathrm{H}_{4}+\mathrm{HO}_{2}$ & $3.80 \times 10^{-15}$ & Atkinson et al. [64] \\
\hline (R35) & $\mathrm{C}_{2} \mathrm{H}_{5}+\mathrm{O}_{2}(+\mathrm{M}) \rightarrow \mathrm{C}_{2} \mathrm{H}_{5} \mathrm{O}_{2}(+\mathrm{M})$ & $7.19 \times 10^{-12}$ & Atkinson et al. [64] \\
\hline (R36) & $\begin{array}{l}\mathrm{C}_{2} \mathrm{H}_{4}+\mathrm{OH}(+\mathrm{M}) \stackrel{1.5 \mathrm{O}_{2}}{\longrightarrow} \\
\mathrm{CH}_{3} \mathrm{O}_{2}+\mathrm{CO}+\mathrm{H}_{2} \mathrm{O}(+\mathrm{M})\end{array}$ & $9.20 \times 10^{-12}$ & Atkinson et al. [64] \\
\hline (R37) & $\mathrm{C}_{2} \mathrm{H}_{4}+\mathrm{O}_{3} \rightarrow \mathrm{HCHO}+\mathrm{CO}+\mathrm{H}_{2} \mathrm{O}$ & $4.33 \times 10^{-19}$ & Sander et al. [68] \\
\hline (R38) & $\begin{array}{l}\mathrm{C}_{2} \mathrm{H}_{2}+\mathrm{OH}(+\mathrm{M}) \stackrel{1.5 \mathrm{O}_{2}}{\longrightarrow} \\
\mathrm{HCHO}+\mathrm{CO}+\mathrm{HO}_{2}(+\mathrm{M})\end{array}$ & $8.32 \times 10^{-13}$ & Atkinson et al. [64] \\
\hline (R39) & $\mathrm{C}_{3} \mathrm{H}_{8}+\mathrm{OH} \stackrel{2 \mathrm{O}_{2}}{\longrightarrow} \mathrm{C}_{2} \mathrm{H}_{5} \mathrm{O}_{2}+\mathrm{CO}+2 \mathrm{H}_{2} \mathrm{O}$ & $7.87 \times 10^{-13}$ & Atkinson et al. [64] \\
\hline$(\mathrm{R} 40)$ & $\mathrm{HCHO}+\mathrm{OH} \stackrel{\mathrm{O}_{2}}{\longrightarrow} \mathrm{CO}+\mathrm{H}_{2} \mathrm{O}+\mathrm{HO}_{2}$ & $9.11 \times 10^{-12}$ & Atkinson et al. [64] \\
\hline$(\mathrm{R} 41)$ & $\mathrm{CH}_{3} \mathrm{CHO}+\mathrm{OH} \stackrel{\mathrm{O}_{2}}{\longrightarrow} \mathrm{CH}_{3} \mathrm{CO}_{3}+\mathrm{H}_{2} \mathrm{O}$ & $1.81 \times 10^{-11}$ & Atkinson et al. [64] \\
\hline (R42) & $\mathrm{CH}_{3} \mathrm{O}_{2}+\mathrm{HO}_{2} \rightarrow \mathrm{CH}_{3} \mathrm{O}_{2} \mathrm{H}+\mathrm{O}_{2}$ & $7.30 \times 10^{-12}$ & Atkinson et al. [64] \\
\hline (R43) & $\mathrm{CH}_{3} \mathrm{O}_{2}+\mathrm{HO}_{2} \rightarrow \mathrm{HCHO}+\mathrm{H}_{2} \mathrm{O}+\mathrm{O}_{2}$ & $7.78 \times 10^{-13}$ & Atkinson et al. [64] \\
\hline (R44) & $\mathrm{CH}_{3} \mathrm{OOH}+\mathrm{OH} \rightarrow \mathrm{CH}_{3} \mathrm{O}_{2}+\mathrm{H}_{2} \mathrm{O}$ & $3.96 \times 10^{-12}$ & Atkinson et al. [64] \\
\hline (R45) & $\mathrm{CH}_{3} \mathrm{OOH}+\mathrm{OH} \rightarrow \mathrm{HCHO}+\mathrm{OH}+\mathrm{H}_{2} \mathrm{O}$ & $2.09 \times 10^{-12}$ & Atkinson et al. [64] \\
\hline (R46) & $\mathrm{CH}_{3} \mathrm{OOH}+\mathrm{Br} \rightarrow \mathrm{CH}_{3} \mathrm{O}_{2}+\mathrm{HBr}$ & $5.18 \times 10^{-15}$ & Mallard et al. [69] \\
\hline (R47) & $\mathrm{CH}_{3} \mathrm{O}_{2}+\mathrm{CH}_{3} \mathrm{O}_{2} \rightarrow \mathrm{CH}_{3} \mathrm{OH}+\mathrm{HCHO}+\mathrm{O}_{2}$ & $2.76 \times 10^{-13}$ & Atkinson et al. [64] \\
\hline$(\mathrm{R} 48)$ & $\mathrm{CH}_{3} \mathrm{O}_{2}+\mathrm{CH}_{3} \mathrm{O}_{2} \stackrel{\mathrm{O}_{2}}{\longrightarrow} 2 \mathrm{HCHO}+2 \mathrm{HO}_{2}$ & $1.35 \times 10^{-13}$ & Atkinson et al. [64] \\
\hline (R49) & $\mathrm{CH}_{3} \mathrm{OH}+\mathrm{OH} \stackrel{\mathrm{O}_{2}}{\longrightarrow} \mathrm{HCHO}+\mathrm{HO}_{2}+\mathrm{H}_{2} \mathrm{O}$ & $6.36 \times 10^{-13}$ & Atkinson et al. [64] \\
\hline (R50) & $\mathrm{C}_{2} \mathrm{H}_{5} \mathrm{O}_{2}+\mathrm{C}_{2} \mathrm{H}_{5} \mathrm{O}_{2} \rightarrow \mathrm{C}_{2} \mathrm{H}_{5} \mathrm{O}+\mathrm{C}_{2} \mathrm{H}_{5} \mathrm{O}+\mathrm{O}_{2}$ & $6.40 \times 10^{-14}$ & Atkinson et al. [64] \\
\hline (R51) & $\mathrm{C}_{2} \mathrm{H}_{5} \mathrm{O}+\mathrm{O}_{2} \rightarrow \mathrm{CH}_{3} \mathrm{CHO}+\mathrm{HO}_{2}$ & $7.44 \times 10^{-15}$ & Sander et al. [68] \\
\hline (R52) & $\mathrm{C}_{2} \mathrm{H}_{5} \mathrm{O}+\mathrm{O}_{2} \rightarrow \mathrm{CH}_{3} \mathrm{O}_{2}+\mathrm{HCHO}$ & $7.51 \times 10^{-17}$ & Sander et al. [68] \\
\hline (R53) & $\mathrm{C}_{2} \mathrm{H}_{5} \mathrm{O}_{2}+\mathrm{HO}_{2} \rightarrow \mathrm{C}_{2} \mathrm{H}_{5} \mathrm{OOH}+\mathrm{O}_{2}$ & $1.24 \times 10^{-11}$ & Atkinson et al. [64] \\
\hline (R54) & $\mathrm{C}_{2} \mathrm{H}_{5} \mathrm{OOH}+\mathrm{OH} \rightarrow \mathrm{C}_{2} \mathrm{H}_{5} \mathrm{O}_{2}+\mathrm{H}_{2} \mathrm{O}$ & $8.21 \times 10^{-12}$ & Sander et al. [68] \\
\hline (R55) & $\mathrm{C}_{2} \mathrm{H}_{5} \mathrm{OOH}+\mathrm{Br} \rightarrow \mathrm{C}_{2} \mathrm{H}_{5} \mathrm{O}_{2}+\mathrm{HBr}$ & $5.19 \times 10^{-15}$ & Sander et al. [68] \\
\hline (R56) & $\mathrm{OH}+\mathrm{OH}(+\mathrm{M}) \longrightarrow \mathrm{H}_{2} \mathrm{O}_{2}(+\mathrm{M})$ & $5.33 \times 10^{-12}$ & Atkinson et al. [64] \\
\hline (R57) & $\mathrm{H}_{2} \mathrm{O}_{2}+\mathrm{h} v \rightarrow 2 \mathrm{OH}$ & $2.00 \times 10^{-6}$ & Lehrer et al. [18] \\
\hline (R58) & $\mathrm{HCHO}+\mathrm{h} v \stackrel{2 \mathrm{O}_{2}}{\longrightarrow} 2 \mathrm{HO}_{2}+\mathrm{CO}$ & $5.50 \times 10^{-6}$ & Lehrer et al. [18] \\
\hline (R59) & $\mathrm{HCHO}+\mathrm{h} v \rightarrow \mathrm{H}_{2}+\mathrm{CO}$ & $9.60 \times 10^{-6}$ & Lehrer et al. [18] \\
\hline (R60) & $\mathrm{C}_{2} \mathrm{H}_{4} \mathrm{O}+\mathrm{h} v \rightarrow \mathrm{CH}_{3} \mathrm{O}_{2}+\mathrm{CO}++\mathrm{HO}_{2}$ & $6.90 \times 10^{-7}$ & Lehrer et al. [18] \\
\hline (R61) & $\mathrm{CH}_{3} \mathrm{O}_{2} \mathrm{H}+\mathrm{h} v \rightarrow \mathrm{OH}+\mathrm{HCHO}+\mathrm{HO}_{2}$ & $1.20 \times 10^{-6}$ & Lehrer et al. [18] \\
\hline (R62) & $\mathrm{C}_{2} \mathrm{H}_{5} \mathrm{O}_{2} \mathrm{H}+\mathrm{h} v \rightarrow \mathrm{C}_{2} \mathrm{H}_{5} \mathrm{O}+\mathrm{OH}$ & $1.20 \times 10^{-6}$ & Lehrer et al. [18] \\
\hline
\end{tabular}


Table A1. Cont.

\begin{tabular}{|c|c|c|c|}
\hline $\begin{array}{l}\text { Reaction } \\
\text { Number }\end{array}$ & Reaction & $\begin{array}{l}k \\
{\left[\left(\text { molec. } \mathrm{cm}^{-3}\right)^{1-n} \mathrm{~s}^{-1}\right]}\end{array}$ & Reference \\
\hline (R63) & $\mathrm{NO}+\mathrm{O}_{3} \rightarrow \mathrm{NO}_{2}+\mathrm{O}_{2}$ & $8.73 \times 10^{-15}$ & Atkinson et al. [64] \\
\hline (R64) & $\mathrm{NO}+\mathrm{HO}_{2} \rightarrow \mathrm{NO}_{2}+\mathrm{OH}$ & $1.03 \times 10^{-11}$ & Atkinson et al. [64] \\
\hline (R65) & $\mathrm{NO}_{2}+\mathrm{O}_{3} \rightarrow \mathrm{NO}_{3}+\mathrm{O}_{2}$ & $9.74 \times 10^{-18}$ & Atkinson et al. [64] \\
\hline (R66) & $\mathrm{NO}_{2}+\mathrm{OH}(+\mathrm{M}) \rightarrow \mathrm{HNO}_{3}(+\mathrm{M})$ & $1.42 \times 10^{-11}$ & Atkinson et al. [64] \\
\hline (R67) & $\mathrm{NO}+\mathrm{NO}_{3} \rightarrow 2 \mathrm{NO}_{2}$ & $2.76 \times 10^{-11}$ & Atkinson et al. [64] \\
\hline (R68) & $\mathrm{HONO}+\mathrm{OH} \rightarrow \mathrm{NO}_{2}+\mathrm{H}_{2} \mathrm{O}$ & $6.85 \times 10^{-12}$ & Atkinson et al. [64] \\
\hline (R69) & $\mathrm{HO}_{2}+\mathrm{NO}_{2}(+\mathrm{M}) \rightarrow \mathrm{HNO}_{4}(+\mathrm{M})$ & $1.66 \times 10^{-12}$ & Atkinson et al. [64] \\
\hline (R70) & $\mathrm{HNO}_{4}(+\mathrm{M}) \rightarrow \mathrm{NO}_{2}+\mathrm{HO}_{2}(+\mathrm{M})$ & $2.71 \times 10^{-4}$ & Atkinson et al. [64] \\
\hline (R71) & $\mathrm{HNO}_{4}+\mathrm{OH} \rightarrow \mathrm{NO}_{2}+\mathrm{H}_{2} \mathrm{O}+\mathrm{O}_{2}$ & $4.64 \times 10^{-12}$ & Atkinson et al. [64] \\
\hline (R72) & $\mathrm{NO}+\mathrm{OH}(+\mathrm{M}) \rightarrow \mathrm{HONO}(+\mathrm{M})^{2}$ & $1.15 \times 10^{-11}$ & Atkinson et al. [64] \\
\hline (R73) & $\mathrm{OH}+\mathrm{NO}_{3} \rightarrow \mathrm{NO}_{2}+\mathrm{HO}_{2}$ & $2.00 \times 10^{-11}$ & Atkinson et al. [64] \\
\hline (R74) & $\mathrm{HNO}_{3}+\mathrm{h} v \rightarrow \mathrm{NO}_{2}+\mathrm{OH}$ & $4.40 \times 10^{-8}$ & Lehrer et al. [18] \\
\hline (R75) & $\mathrm{NO}_{2}+\mathrm{h} v \stackrel{\mathrm{O}_{2}}{\longrightarrow} \mathrm{NO}+\mathrm{O}_{3}$ & $3.50 \times 10^{-3}$ & Lehrer et al. [18] \\
\hline$(\mathrm{R} 76)$ & $\mathrm{NO}_{3}+\mathrm{h} v \stackrel{\mathrm{O}_{2}}{\longrightarrow} \mathrm{NO}_{2}+\mathrm{O}_{3}$ & $1.40 \times 10^{-1}$ & Lehrer et al. [18] \\
\hline (R77) & $\mathrm{NO}_{3}+\mathrm{h} v \rightarrow \mathrm{NO}+\mathrm{O}_{2}$ & $1.70 \times 10^{-2}$ & Lehrer et al. [18] \\
\hline (R78) & $\mathrm{NO}+\mathrm{CH}_{3} \mathrm{O}_{2} \stackrel{\mathrm{O}_{2}}{\longrightarrow} \mathrm{HCHO}+\mathrm{HO}_{2}+\mathrm{NO}_{2}$ & $9.28 \times 10^{-12}$ & Atkinson et al. [64] \\
\hline$(\mathrm{R} 79)$ & $\mathrm{NO}_{3}+\mathrm{CH}_{3} \mathrm{OH} \stackrel{\mathrm{O}_{2}}{\longrightarrow} \mathrm{HCHO}+\mathrm{HO}_{2}+\mathrm{HNO}_{3}$ & $3.25 \times 10^{-17}$ & Atkinson et al. [64] \\
\hline$(\mathrm{R} 80)$ & $\mathrm{NO}_{3}+\mathrm{HCHO} \stackrel{\mathrm{O}_{2}}{\longrightarrow} \mathrm{CO}+\mathrm{HO}_{2}+\mathrm{HNO}_{3}$ & $5.60 \times 10^{-16}$ & Atkinson et al. [64] \\
\hline$(\mathrm{R} 81)$ & $\mathrm{NO}+\mathrm{C}_{2} \mathrm{H}_{5} \mathrm{O}_{2} \stackrel{\mathrm{O}_{2}}{\longrightarrow} \mathrm{CH}_{3} \mathrm{CHO}+\mathrm{NO}_{2}+\mathrm{HO}_{2}$ & $1.13 \times 10^{-11}$ & Atkinson et al. [64] \\
\hline (R82) & $\mathrm{NO}+\mathrm{CH}_{3} \mathrm{CO}_{3} \stackrel{\mathrm{O}_{2}}{\longrightarrow} \mathrm{CH}_{3} \mathrm{O}_{2}+\mathrm{NO}_{2}+\mathrm{CO}_{2}$ & $2.30 \times 10^{-11}$ & Atkinson et al. [64] \\
\hline (R83) & $\mathrm{NO}_{2}+\mathrm{CH}_{3} \mathrm{CO}_{3}(+\mathrm{M}) \rightarrow \mathrm{PAN}(+\mathrm{M})$ & $1.23 \times 10^{-11}$ & Atkinson et al. [64] \\
\hline (R84) & $\mathrm{Br}+\mathrm{NO}_{2}(+\mathrm{M}) \rightarrow \mathrm{BrNO}_{2}(+\mathrm{M})$ & $5.21 \times 10^{-12}$ & Atkinson et al. [64] \\
\hline (R85) & $\mathrm{Br}+\mathrm{NO}_{3} \rightarrow \mathrm{BrO}+\mathrm{NO}_{2}$ & $1.60 \times 10^{-11}$ & Atkinson et al. [64] \\
\hline (R86) & $\mathrm{BrO}+\mathrm{NO}_{2}(+\mathrm{M}) \rightarrow \mathrm{BrONO}_{2}(+\mathrm{M})$ & $3.48 \times 10^{-12}$ & Atkinson et al. [64] \\
\hline (R87) & $\mathrm{BrO}+\mathrm{NO} \rightarrow \mathrm{Br}+\mathrm{NO}_{2}$ & $2.38 \times 10^{-11}$ & Atkinson et al. [64] \\
\hline (R88) & $\mathrm{BrONO}_{2}+\mathrm{h} v \rightarrow \mathrm{NO}_{2}+\mathrm{BrO}$ & $3.40 \times 10^{-4}$ & Lehrer et al. [18] \\
\hline (R89) & $\mathrm{BrNO}_{2}+\mathrm{h} v \rightarrow \mathrm{NO}_{2}+\mathrm{Br}$ & $9.30 \times 10^{-5}$ & Lehrer et al. [18] \\
\hline (R90) & $\mathrm{BrONO}_{2}+\mathrm{H}_{2} \mathrm{O} \stackrel{\text { aerosol }}{\longrightarrow} \mathrm{HOBr}+\mathrm{HNO}_{3}$ & $2.76 \times 10^{-4}$ & Cao et al. [44] \\
\hline (R91) & $\mathrm{PAN}+\mathrm{h} v \rightarrow \mathrm{NO}_{2}+\mathrm{CH}_{3} \mathrm{CO}_{3}$ & $6.79 \times 10^{-7}$ & $\begin{array}{l}\text { Fishman and } \\
\text { Carney [70] }\end{array}$ \\
\hline (R92) & $\mathrm{BrONO}_{2}+\mathrm{H}_{2} \mathrm{O} \stackrel{\text { ice }}{\longrightarrow} \mathrm{HOBr}+\mathrm{HNO}_{3}$ & $3.30 \times 10^{-5}$ & Cao et al. [44] \\
\hline (R93) & $\mathrm{CH}_{3} \mathrm{O}_{2} \mathrm{H}+\mathrm{Cl} \rightarrow \mathrm{CH}_{3} \mathrm{O}_{2}+\mathrm{HCl}$ & $5.90 \times 10^{-11}$ & Atkinson et al. [64] \\
\hline (R94) & $\mathrm{C}_{2} \mathrm{H}_{5} \mathrm{O}_{2} \mathrm{H}+\mathrm{Cl} \rightarrow \mathrm{C}_{2} \mathrm{H}_{5} \mathrm{O}_{2}+\mathrm{HCl}$ & $5.70 \times 10^{-11}$ & Atkinson et al. [64] \\
\hline (R95) & $\mathrm{Cl}+\mathrm{HO}_{2} \rightarrow \mathrm{HCl}+\mathrm{O}_{2}$ & $3.61 \times 10^{-11}$ & Atkinson et al. [64] \\
\hline (R96) & $\mathrm{Cl}+\mathrm{HO}_{2} \rightarrow \mathrm{ClO}+\mathrm{HO}$ & $6.92 \times 10^{-12}$ & Atkinson et al. [64] \\
\hline (R97) & $\mathrm{Cl}+\mathrm{H}_{2} \mathrm{O}_{2} \rightarrow \mathrm{HCl}+\mathrm{HO}_{2}$ & $2.46 \times 10^{-13}$ & Atkinson et al. [64] \\
\hline (R98) & $\mathrm{Cl}+\mathrm{O}_{3} \rightarrow \mathrm{ClO}+\mathrm{O}_{2}$ & $1.06 \times 10^{-11}$ & Atkinson et al. [64] \\
\hline (R99) & $\mathrm{Cl}+\mathrm{CH}_{4} \rightarrow \mathrm{HCl}+\mathrm{CH}_{3} \mathrm{O}_{2}$ & $5.40 \times 10^{-14}$ & Atkinson et al. [64] \\
\hline (R100) & $\mathrm{Cl}+\mathrm{C}_{2} \mathrm{H}_{2} \rightarrow 2 \mathrm{CO}+2 \mathrm{HO}_{2}+\mathrm{Cl}$ & $2.00 \times 10^{-11}$ & Borken [65] \\
\hline (R101) & $\mathrm{Cl}+\mathrm{C}_{2} \mathrm{H}_{4} \rightarrow 2 \mathrm{CO}+\mathrm{HO}_{2}+\mathrm{HCl}$ & $4.24 \times 10^{-11}$ & Borken [65] \\
\hline (R102) & $\mathrm{Cl}+\mathrm{C}_{2} \mathrm{H}_{4} \rightarrow 2 \mathrm{CO}+2 \mathrm{HO}_{2}+\mathrm{Cl}+\mathrm{H}_{2} \mathrm{O}$ & $4.00 \times 10^{-11}$ & Atkinson et al. [64] \\
\hline (R103) & $\mathrm{Cl}+\mathrm{C}_{2} \mathrm{H}_{4} \rightarrow 2 \mathrm{CO}+\mathrm{HO}_{2}+\mathrm{HCl}+\mathrm{H}_{2} \mathrm{O}$ & $8.51 \times 10^{-11}$ & Atkinson et al. [64] \\
\hline (R104) & $\mathrm{Cl}+\mathrm{C}_{2} \mathrm{H}_{6} \rightarrow \mathrm{C}_{2} \mathrm{H}_{5}+\mathrm{HCl}$ & $5.63 \times 10^{-11}$ & Atkinson et al. [64] \\
\hline (R105) & $\mathrm{Cl}+\mathrm{C}_{3} \mathrm{H}_{8} \rightarrow \mathrm{C}_{2} \mathrm{H}_{5} \mathrm{O}_{2}+\mathrm{HCl}+\mathrm{H}_{2} \mathrm{O}+\mathrm{CO}_{2}$ & $1.40 \times 10^{-10}$ & Atkinson et al. [64] \\
\hline (R106) & $\mathrm{Cl}+\mathrm{CH}_{2} \mathrm{O} \rightarrow \mathrm{HCl}+\mathrm{CO}+\mathrm{HO}_{2}$ & $7.10 \times 10^{-11}$ & Atkinson et al. [64] \\
\hline (R107) & $\mathrm{Cl}+\mathrm{C}_{2} \mathrm{H}_{4} \mathrm{O} \rightarrow \mathrm{CH}_{3} \mathrm{CO}_{3}+\mathrm{HCl}$ & $8.00 \times 10^{-11}$ & Atkinson et al. [64] \\
\hline (R108) & $\mathrm{HO}+\mathrm{Cl}_{2} \rightarrow \mathrm{HOCl}+\mathrm{Cl}$ & $3.44 \times 10^{-14}$ & Atkinson et al. [64] \\
\hline (R109) & $\mathrm{HO}+\mathrm{HCl} \rightarrow \mathrm{Cl}+\mathrm{H}_{2} \mathrm{O}$ & $7.10 \times 10^{-13}$ & Atkinson et al. [64] \\
\hline
\end{tabular}


Table A1. Cont.

\begin{tabular}{|c|c|c|c|}
\hline $\begin{array}{l}\text { Reaction } \\
\text { Number }\end{array}$ & Reaction & $\begin{array}{l}k \\
{\left[\left(\text { molec. } \mathrm{cm}^{-3}\right)^{1-n} \mathrm{~s}^{-1}\right]}\end{array}$ & Reference \\
\hline (R110) & $\mathrm{HO}+\mathrm{HOCl} \rightarrow \mathrm{ClO}+\mathrm{H}_{2} \mathrm{O}$ & $5.00 \times 10^{-13}$ & Atkinson et al. [64] \\
\hline (R111) & $\mathrm{HO}+\mathrm{ClO} \rightarrow \mathrm{Cl}+\mathrm{HO}_{2}$ & $2.20 \times 10^{-11}$ & Atkinson et al. [64] \\
\hline (R112) & $\mathrm{HO}+\mathrm{ClO} \rightarrow \mathrm{HCl}+\mathrm{O}_{2}$ & $1.40 \times 10^{-12}$ & Atkinson et al. [64] \\
\hline (R113) & $2 \mathrm{ClO} \rightarrow \mathrm{Cl}_{2}+\mathrm{O}_{2}$ & $2.11 \times 10^{-15}$ & Atkinson et al. [64] \\
\hline (R114) & $2 \mathrm{ClO} \rightarrow 2 \mathrm{Cl}+\mathrm{O}_{2}$ & $2.25 \times 10^{-15}$ & Atkinson et al. [64] \\
\hline (R115) & $2 \mathrm{ClO} \rightarrow \mathrm{Cl}+\mathrm{OClO}$ & $1.73 \times 10^{-15}$ & Atkinson et al. [64] \\
\hline (R116) & $2 \mathrm{ClO} \rightarrow \mathrm{Cl}_{2} \mathrm{O}_{2}$ & $5.07 \times 10^{-13}$ & Atkinson et al. [64] \\
\hline (R117) & $\mathrm{Cl}_{2} \mathrm{O}_{2} \rightarrow 2 \mathrm{ClO}$ & $6.51 \times 10^{-1}$ & Atkinson et al. [64] \\
\hline (R118) & $\mathrm{ClO}+\mathrm{HO}_{2} \rightarrow \mathrm{HOCl}+\mathrm{O}_{2}$ & $8.22 \times 10^{-12}$ & Atkinson et al. [64] \\
\hline (R119) & $\mathrm{ClO}+\mathrm{CH}_{3} \mathrm{O}_{2} \rightarrow \mathrm{Cl}+\mathrm{CH}_{2} \mathrm{O}+\mathrm{HO}_{2}$ & $2.22 \times 10^{-12}$ & Atkinson et al. [64] \\
\hline (R120) & $\mathrm{ClO}+\mathrm{NO} \rightarrow \mathrm{Cl}+\mathrm{NO}_{2}$ & $1.95 \times 10^{-11}$ & Atkinson et al. [64] \\
\hline (R121) & $\mathrm{ClO}+\mathrm{NO}_{2} \rightarrow \mathrm{ClONO}_{2}$ & $3.48 \times 10^{-12}$ & Atkinson et al. [64] \\
\hline (R122) & $\mathrm{Cl}+\mathrm{ClONO}_{2} \rightarrow \mathrm{Cl}_{2}+\mathrm{NO}_{3}$ & $1.09 \times 10^{-11}$ & Atkinson et al. [64] \\
\hline (R123) & $\mathrm{OClO}+\mathrm{NO} \rightarrow \mathrm{NO}_{2}+\mathrm{ClO}$ & $4.27 \times 10^{-13}$ & Atkinson et al. [64] \\
\hline (R124) & $\mathrm{HO}+\mathrm{ClONO}_{2} \rightarrow \mathrm{HOCl}+\mathrm{NO}_{3}$ & $3.34 \times 10^{-13}$ & Atkinson et al. [64] \\
\hline (R125) & $\mathrm{ClO}+\mathrm{BrO} \rightarrow \mathrm{Br}+\mathrm{OClO}$ & $8.47 \times 10^{-12}$ & Atkinson et al. [64] \\
\hline (R126) & $\mathrm{ClO}+\mathrm{BrO} \rightarrow \mathrm{Br}+\mathrm{Cl}+\mathrm{O}_{2}$ & $6.80 \times 10^{-12}$ & Atkinson et al. [64] \\
\hline (R127) & $\mathrm{ClO}+\mathrm{BrO} \rightarrow \mathrm{BrCl}+\mathrm{O}_{2}$ & $1.12 \times 10^{-12}$ & Atkinson et al. [64] \\
\hline (R128) & $\mathrm{Br}+\mathrm{OClO} \rightarrow \mathrm{BrO}+\mathrm{ClO}$ & $1.75 \times 10^{-13}$ & Atkinson et al. [64] \\
\hline (R129) & $\mathrm{Br}+\mathrm{Cl}_{2} \mathrm{O}_{2} \rightarrow \mathrm{BrCl}+\mathrm{ClOO}$ & $3.00 \times 10^{-12}$ & Atkinson et al. [64] \\
\hline (R130) & $\mathrm{Br}_{2}+\mathrm{Cl} \rightarrow \mathrm{BrCl}+\mathrm{Br}$ & $1.20 \times 10^{-10}$ & $\begin{array}{l}\text { Sander and Crutzen } \\
\text { [53] }\end{array}$ \\
\hline (R131) & $\mathrm{BrCl}+\mathrm{Br} \rightarrow \mathrm{Br}_{2}+\mathrm{Cl}$ & $3.30 \times 10^{-15}$ & $\begin{array}{l}\text { Sander and Crutzen } \\
\text { [53] }\end{array}$ \\
\hline (R132) & $\mathrm{Br}+\mathrm{Cl}_{2} \rightarrow \mathrm{BrCl}+\mathrm{Cl}$ & $1.10 \times 10^{-15}$ & $\begin{array}{l}\text { Sander and Crutzen } \\
\text { [53] }\end{array}$ \\
\hline (R133) & $\mathrm{BrCl}+\mathrm{Cl} \rightarrow \mathrm{Br}+\mathrm{Cl}_{2}$ & $1.50 \times 10^{-11}$ & Sander and Crutzen \\
\hline (R134) & $\mathrm{HOBr} \rightarrow \mathrm{BrCl}+\mathrm{H}_{2} \mathrm{O}$ & $1.51 \times 10^{-5}$ & Atkinson et al. [64] \\
\hline (R135) & $\mathrm{BrCl}+\mathrm{h} v \rightarrow \mathrm{Br}+\mathrm{Cl}$ & $5.70 \times 10^{-3}$ & Röth [71] \\
\hline (R136) & $\mathrm{Cl}_{2}+\mathrm{h} v \rightarrow \mathrm{Cl}$ & $8.50 \times 10^{-4}$ & Röth [71] \\
\hline (R137) & $\mathrm{ClO}+\mathrm{h} v \rightarrow \mathrm{Cl}+\mathrm{O}_{3}$ & $5.00 \times 10^{-7}$ & Röth [71] \\
\hline (R138) & $\mathrm{HOCl}+\mathrm{h} v \rightarrow \mathrm{HO}+\mathrm{Cl}$ & $8.60 \times 10^{-5}$ & Röth [71] \\
\hline (R139) & $\mathrm{ClONO}_{2}+\mathrm{h} v \rightarrow \mathrm{NO}_{3}+\mathrm{Cl}$ & $1.30 \times 10^{-2}$ & Röth [71] \\
\hline (R140) & $\mathrm{OClO}+\mathrm{h} v \rightarrow \mathrm{O}_{3}+\mathrm{ClO}$ & $3.60 \times 10^{-2}$ & Röth [71] \\
\hline (R141) & $\mathrm{HOBr}+\mathrm{HCl} \rightarrow \mathrm{BrCl}+\mathrm{H}_{2} \mathrm{O}$ & $5.37 \times 10^{-14}$ & Atkinson et al. [64] \\
\hline
\end{tabular}

\section{References}

1. Seinfeld, J.H.; Pandis, S.N. Atmospheric Chemistry and Physics: From Air Pollution to Climate Change; John Wiley \& Sons, Inc.: Hoboken, NJ, USA, 2006.

2. Akimoto, H. Atmospheric Reaction Chemistry; Springer: Tokyo, Japan, 2016.

3. Zhang, Z.; Rao, J.; Guo, D.; Zhang, W.; Li, L.; Tang, Z.; Shi, C.; Su, Y.; Zhang, F. Interdecadal Variations of the Midlatitude Ozone Valleys in Summer. Atmosphere 2019, 10, 677. [CrossRef]

4. Cao, C.; Chen, Y.; Rao, J.; Liu, S.; Li, S.; Ma, M.; Wang, Y. Statistical Characteristics of Major Sudden Stratospheric Warming Events in CESM1-WACCM: A Comparison with the JRA55 and NCEP/NCAR Reanalyses. Atmosphere 2019, 10, 519. [CrossRef]

5. Liu, S.; Chen, Y.; Rao, J.; Cao, C.; Li, S.; Ma, M.; Wang, Y. Parallel Comparison of Major Sudden Stratospheric Warming Events in CESM1-WACCM and CESM2-WACCM. Atmosphere 2019, 10, 679. [CrossRef]

6. Lippmann, M. Health effects of tropospheric ozone. Environ. Sci. Technol. 1991, 25, 1954-1962. [CrossRef]

7. Finlayson-Pitts, B.; Pitts, J., Jr. Atmospheric chemistry of tropospheric ozone formation: Scientific and regulatory implications. Air Waste 1993, 43, 1091-1100. [CrossRef] 
8. Finlayson-Pitts, B.J.; Pitts, J.N. Tropospheric air pollution: ozone, airborne toxics, polycyclic aromatic hydrocarbons, and particles. Science 1997, 276, 1045-1051. [CrossRef] [PubMed]

9. Cao, L.; Gao, M.; Li, S.; Yi, Z.; Meng, X. Sensitivity analysis of the dependence of the Carbon Bond Mechanism IV (CBM-IV) on the initial air composition under an urban condition. Atmos. Environ. 2019, 215, 116860. [CrossRef]

10. Cao, L.; Li, S.; Yi, Z.; Gao, M. Simplification of Carbon Bond Mechanism IV (CBM-IV) under Different Initial Conditions by Using Concentration Sensitivity Analysis. Molecules 2019, 24, 2463. [CrossRef]

11. Vingarzan, R. A review of surface ozone background levels and trends. Atmos. Environ. 2004, 38, $3431-3442$. [CrossRef]

12. Solomon, S. Stratospheric ozone depletion: A review of concepts and history. Rev. Geophys. 1999, 37, $275-316$. [CrossRef]

13. Simpson, W.R.; von Glasow, R.; Riedel, K.; Anderson, P.; Ariya, P.; Bottenheim, J.; Burrows, J.; Carpenter, L.J.; Frieß, U.; Goodsite, M.E.; et al. Halogens and their role in polar boundary-layer ozone depletion. Atmos. Chem. Phys. 2007, 7, 4375-4418. [CrossRef]

14. Jones, A.E.; Anderson, P.S.; Wolff, E.W.; Roscoe, H.K.; Marshall, G.J.; Richter, A.; Brough, N.; Colwell, S.R. Vertical structure of Antarctic tropospheric ozone depletion events: characteristics and broader implications. Atmos. Chem. Phys. 2010, 10, 7775-7794. [CrossRef]

15. Farman, J.C.; Gardiner, B.G.; Shanklin, J.D. Large losses of total ozone in Antarctica reveal seasonal $\mathrm{ClO}_{\mathrm{x}} / \mathrm{NO}_{\mathrm{x}}$ interaction. Nature 1985, 315, 207-210. [CrossRef]

16. Bottenheim, J.; Gallant, A.; Brice, K. Measurements of $\mathrm{NO}_{\mathrm{Y}}$ species and $\mathrm{O}_{3}$ at $82^{\circ} \mathrm{N}$ latitude. Geophys. Res. Lett. 1986, 13, 113-116. [CrossRef]

17. Kreher, K.; Johnston, P.V.; Wood, S.W.; Nardi, B.; Platt, U. Ground-based measurements of tropospheric and stratospheric BrO at Arrival Heights, Antarctica. Geophys. Res. Lett. 1997, 24, 3021-3024. [CrossRef]

18. Lehrer, E.; Hönninger, G.; Platt, U. A one dimensional model study of the mechanism of halogen liberation and vertical transport in the polar troposphere. Atmos. Chem. Phys. 2004, 4, 2427-2440. [CrossRef]

19. Koo, J.H.; Wang, Y.; Jiang, T.; Deng, Y.; Oltmans, S.J.; Solberg, S. Influence of climate variability on near-surface ozone depletion events in the Arctic spring. Geophys. Res. Lett. 2014, 41, 2582-2589. [CrossRef]

20. Steffen, A.; Douglas, T.A.; Amyot, M.; Ariya, P.A.; Aspmo, K.; Berg, T.; Bottenheim, J.W.; Brooks, S.; Cobbett, F.; Dastoor, A.; et al. A synthesis of atmospheric mercury depletion event chemistry in the atmosphere and snow. Atmos. Chem. Phys. 2008, 8, 1445-1482. [CrossRef]

21. Oltmans, S.J. Surface ozone measurements in clean air. J. Geophys. Res. Oceans 1981, 86, 1174-1180. [CrossRef]

22. Hönninger, G.; Platt, U. Observations of $\mathrm{BrO}$ and its vertical distribution during surface ozone depletion at Alert. Atmos. Environ. 2002, 36, 2481-2489. [CrossRef]

23. Platt, U.; Janssen, C. Observation and role of the free radicals $\mathrm{NO}_{3}, \mathrm{ClO}, \mathrm{BrO}$ and $\mathrm{IO}$ in the troposphere. Faraday Discuss. 1995, 100, 175-198. [CrossRef]

24. Platt, U.; Lehrer, E. Arctic Tropospheric Ozone Chemistry, ARCTOC; Number 64 in Air Pollution Research Report; European Commission Directorate-General, Science, Research and Development: Luxembourg, 1997.

25. Wennberg, P. Atmospheric chemistry: Bromine explosion. Nature 1999, 397, 299-301. [CrossRef]

26. Tarasick, D.W.; Bottenheim, J.W. Surface ozone depletion episodes in the Arctic and Antarctic from historical ozonesonde records. Atmos. Chem. Phys. 2002, 2, 197-205. [CrossRef]

27. Bottenheim, J.W.; Netcheva, S.; Morin, S.; Nghiem, S.V. Ozone in the boundary layer air over the Arctic Ocean: measurements during the TARA transpolar drift 2006-2008. Atmos. Chem. Phys. 2009, 9, 4545-4557. [CrossRef]

28. Jacobi, H.W.; Morin, S.; Bottenheim, J.W. Observation of widespread depletion of ozone in the springtime boundary layer of the central Arctic linked to mesoscale synoptic conditions. J. Geophys. Res. Atmos. 2010, 115. [CrossRef]

29. Koo, J.H.; Wang, Y.; Kurosu, T.P.; Chance, K.; Rozanov, A.; Richter, A.; Oltmans, S.J.; Thompson, A.M.; Hair, J.W.; Fenn, M.A.; et al. Characteristics of tropospheric ozone depletion events in the Arctic spring: analysis of the ARCTAS, ARCPAC, and ARCIONS measurements and satellite BrO observations. Atmos. Chem. Phys. 2012, 12, 9909-9922. [CrossRef]

30. Gong, S.; Walmsley, J.; Barrie, L.; Hopper, J. Mechanisms for surface ozone depletion and recovery during polar sunrise. Atmos. Environ. 1997, 31, 969-981. [CrossRef] 
31. Strong, C.; Fuentes, J.D.; Davis, R.E.; Bottenheim, J.W. Thermodynamic attributes of Arctic boundary layer ozone depletion. Atmos. Environ. 2002, 36, 2641-2652. [CrossRef]

32. Piot, M.; von Glasow, R. The potential importance of frost flowers, recycling on snow, and open leads for ozone depletion events. Atmos. Chem. Phys. 2008, 8, 2437-2467. [CrossRef]

33. Hu, X.M.; Zhang, F.; Yu, G.; Fuentes, J.D.; Wu, L. Contribution of mixed-phase boundary layer clouds to the termination of ozone depletion events in the Arctic. Geophys. Res. Lett. 2011, 38, L21801. [CrossRef]

34. Honrath, R.E.; Guo, S.; Peterson, M.C.; Dziobak, M.P.; Dibb, J.E.; Arsenault, M. Photochemical production of gas phase $\mathrm{NO}_{\mathrm{x}}$ from ice crystal $\mathrm{NO}_{3}$. J. Geophys. Res. 2000, 105, 24183-24190. [CrossRef]

35. Muthuramu, K.; Shepson, P.B.; Bottenheim, J.W.; Jobson, B.T.; Niki, H.; Anlauf, K.G. Relationships between organic nitrates and surface ozone destruction during Polar Sunrise Experiment 1992. J. Geophys. Res. 1994, 99, 25369-25378. [CrossRef]

36. Endresen, Ø.; Sørgård, E.; Sundet, J.K.; Dalsøren, S.B.; Isaksen, I.S.A.; Berglen, T.F.; Gravir, G. Emission from international sea transportation and environmental impact. J. Geophys. Res. Atmos. 2003, 108. [CrossRef]

37. McConnell, J.C.; Henderson, G.S.; Barrie, L.; Bottenheim, J.; Niki, H.; Langford, C.H.; Templeton, E.M.J. Photochemical bromine production implicated in Arctic boundary-layer ozone depletion. Nature 1992, 355, 150-152. [CrossRef]

38. Fan, S.M.; Jacob, D.J. Surface ozone depletion in Arctic spring sustained by bromine reactions on aerosols. Nature 1992, 359, 522-524. [CrossRef]

39. Beine, H.J.; Jaffe, D.A.; Stordal, F.; Engardt, M.; Solberg, S.; Schmidbauer, N.; Holmen, K. NOx during ozone depletion events in the arctic troposphere at Ny-Ålesund, Svalbard. Tellus B 1997, 49, 556-565. [CrossRef]

40. Evans, M.J.; Jacob, D.J.; Atlas, E.; Cantrell, C.A.; Eisele, F.; Flocke, F.; Fried, A.; Mauldin, R.L.; Ridley, B.A.; Wert, B.; et al. Coupled evolution of $\mathrm{BrO}_{x}-\mathrm{ClO}_{x}-\mathrm{HO}_{x}-\mathrm{NO}_{x}$ chemistry during bromine-catalyzed ozone depletion events in the Arctic boundary layer. J. Geophys. Res. Atmos. 2003, 108. [CrossRef]

41. Bloss, W.J.; Camredon, M.; Lee, J.D.; Heard, D.E.; Plane, J.M.C.; Saiz-Lopez, A.; Bauguitte, S.J.B.; Salmon, R.A.; Jones, A.E. Coupling of $\mathrm{HO}_{x}, \mathrm{NO}_{x}$ and halogen chemistry in the antarctic boundary layer. Atmos. Chem. Phys. 2010, 10, 10187-10209. [CrossRef]

42. Lin, X.; Trainer, M.; Liu, S.C. On the nonlinearity of the tropospheric ozone production. J. Geophys. Res. 1988, 93, 15879-15888. [CrossRef]

43. Liu, S.C.; Trainer, M.; Fehsenfeld, F.C.; Parrish, D.D.; Williams, E.J.; Fahey, D.W.; Hubler, G.; Murphy, P.C. Ozone production in the rural troposphere and the implications for regional and global ozone distributions. J. Geophys. Res. 1987, 92, 4191-4207. [CrossRef]

44. Cao, L.; Sihler, H.; Platt, U.; Gutheil, E. Numerical analysis of the chemical kinetic mechanisms of ozone depletion and halogen release in the polar troposphere. Atmos. Chem. Phys. 2014, 14, 3771-3787. [CrossRef]

45. Custard, K.D.; Thompson, C.R.; Pratt, K.A.; Shepson, P.B.; Liao, J.; Huey, L.G.; Orlando, J.J.; Weinheimer, A.J.; Apel, E.; Hall, S.R.; et al. The $\mathrm{NO}_{\mathrm{x}}$ dependence of bromine chemistry in the Arctic atmospheric boundary layer. Atmos. Chem. Phys. 2015, 15, 10799-10809. [CrossRef]

46. Turanyi, T. KINAL-A program package for kinetic analysis of reaction mechanisms. Comput. Chem. 1990, 14, 253-254. [CrossRef]

47. Jones, A.E.; Weller, R.; Wolff, E.W.; Jacobi, H.W. Speciation and rate of photochemical $\mathrm{NO}$ and $\mathrm{NO}_{2}$ production in Antarctic snow. Geophys. Res. Lett. 2000, 27, 345-348. [CrossRef]

48. Jones, A.E.; Weller, R.; Anderson, P.S.; Jacobi, H.W.; Wolff, E.W.; Schrems, O.; Miller, H. Measurements of $\mathrm{NO}_{x}$ emissions from the Antarctic snowpack. Geophys. Res. Lett. 2001, 28, 1499-1502. [CrossRef]

49. Grannas, A.M.; Jones, A.E.; Dibb, J.; Ammann, M.; Anastasio, C.; Beine, H.J.; Bergin, M.; Bottenheim, J.; Boxe, C.S.; Carver, G.; et al. An overview of snow photochemistry: evidence, mechanisms and impacts. Atmos. Chem. Phys. 2007, 7, 4329-4373. [CrossRef]

50. Jacobi, H.W.; Frey, M.M.; Hutterli, M.A.; Bales, R.C.; Schrems, O.; Cullen, N.J.; Steffen, K.; Koehler, C. Measurements of hydrogen peroxide and formaldehyde exchange between the atmosphere and surface snow at Summit, Greenland. Atmos. Environ. 2002, 36, 2619-2628. [CrossRef]

51. Cao, L.; Platt, U.; Gutheil, E. Role of the boundary layer in the occurrence and termination of the tropospheric ozone depletion events in polar spring. Atmos. Environ. 2016, 132, 98-110. [CrossRef]

52. Schwartz, S. Mass-transport considerations pertinent to aqueous phase reactions of gases in liquid-water clouds. In Chemistry of Multiphase Atmospheric Systems; Jaeschke, W., Ed.; NATO ASI Series; Springer: Berlin/Heidelberg, Germany, 1986; Volume 6, pp. 415-471. 
53. Sander, R.; Crutzen, P.J. Model study indicating halogen activation and ozone destruction in polluted air masses transported to the sea. J. Geophys. Res. Atmos. 1996, 101, 9121-9138. [CrossRef]

54. Hanson, D.R.; Ravishankara, A.R.; Solomon, S. Heterogeneous reactions in sulfuric acid aerosols: A framework for model calculations. J. Geophys. Res. Atmos. 1994, 99, 3615-3629. [CrossRef]

55. Staebler, R.; Toom-Sauntry, D.; Barrie, L.; Langendörfer, U.; Lehrer, E.; Li, S.M.; Dryfhout-Clark, H. Physical and chemical characteristics of aerosols at Spitsbergen in the spring of 1996. J. Geophys. Res. Atmos. 1999, 104, 5515-5529. [CrossRef]

56. Beare, R.; Macvean, M.; Holtslag, A.; Cuxart, J.; Esau, I.; Golaz, J.C.; Jimenez, M.; Khairoutdinov, M.; Kosovic, B.; Lewellen, D.; et al. An intercomparison of large-eddy simulations of the stable boundary layer. Bound. Layer Meteorol. 2006, 118, 247-272. [CrossRef]

57. Huff, A.K.; Abbatt, J.P.D. Kinetics and product yields in the heterogeneous reactions of $\mathrm{HOBr}$ with ice surfaces containing $\mathrm{NaBr}$ and $\mathrm{NaCl}$. J. Phys. Chem. A 2002, 106, 5279-5287. [CrossRef]

58. Valko, P.; Vajda, S. An extended ode solver for sensitivity calculations. Comput. Chem. 1984, 8, $255-271$. [CrossRef]

59. Turányi, T. Sensitivity analysis of complex kinetic systems. Tools and applications. J. Math. Chem. 1990, 5, 203-248. [CrossRef]

60. Liao, J.; Huey, L.G.; Tanner, D.J.; Flocke, F.M.; Orlando, J.J.; Neuman, J.A.; Nowak, J.B.; Weinheimer, A.J.; Hall, S.R.; Smith, J.N.; et al. Observations of inorganic bromine $\left(\mathrm{HOBr}, \mathrm{BrO}\right.$, and $\left.\mathrm{Br}_{2}\right)$ speciation at Barrow, Alaska, in spring 2009. J. Geophys. Res. Atmos. 2012, 117. [CrossRef]

61. Langendörfer, U.; Lehrer, E.; Wagenbach, D.; Platt, U. Observation of filterable bromine variabilities during arctic tropospheric ozone depletion events in high (1 hour) time resolution. J. Atmos. Chem. 1999, 34, 39-54. [CrossRef]

62. Tas, E.; Peleg, M.; Pedersen, D.U.; Matveev, V.; Biazar, A.P.; Luria, M. Measurement-based modeling of bromine chemistry in the Dead Sea boundary layer-Part 2: The influence of $\mathrm{NO}_{2}$ on bromine chemistry at mid-latitude areas. Atmos. Chem. Phys. 2008, 8, 4811-4821. [CrossRef]

63. Tas, E.; Peleg, M.; Pedersen, D.U.; Matveev, V.; Pour Biazar, A.; Luria, M. Measurement-based modeling of bromine chemistry in the boundary layer: 1 . Bromine chemistry at the Dead Sea. Atmos. Chem. Phys. 2006, 6, 5589-5604. [CrossRef]

64. Atkinson, R.; Baulch, D.L.; Cox, R.A.; Crowley, J.N.; Hampson, R.F.; Hynes, R.G.; Jenkin, M.E.; Kerr, J.A.; Rossi, M.; Troe, J. Summary of Evaluated Kinetic and Photochemical Data for Atmospheric Chemistry; Technical Report; 2006. Available online: http://www.iupac-kinetic.ch.cam.ac.uk/ (accessed on 26 November 2019).

65. Borken, J. Ozonabbau durch Halogene in der arktischen Grenzschicht. Ph.D. Thesis, Heidelberg University, Heidelberg, Germany, 1996.

66. Barnes, I.; Becker, K.; Overath, R. Oxidation of organic sulfur compounds. In The Tropospheric Chemistry of Ozone in the Polar Regions; Niki, H., Becker, K., Eds.; Springer: Berlin/Heidelberg, Germany, 1993; Volume 7, pp. 371-383.

67. Aranda, A.; Le Bras, G.; La Verdet, G.; Poulet, G. The $\mathrm{BrO}+\mathrm{Ch}_{3} \mathrm{O}_{2}$ reaction: Kinetics and role in the atmospheric ozone budget. Geophys. Res. Lett. 1997, 24, 2745-2748. [CrossRef]

68. Sander, R.; Vogt, R.; Harris, G.W.; Crutzen, P.J. Modelling the chemistry of ozone, halogen compounds, and hydrocarbons in the arctic troposphere during spring. Tellus B 1997, 49, 522-532. [CrossRef]

69. Mallard, W.G.; Westley, F.; Herron, J.T.; Hampson, R.F.; Frizzel, D.H. NIST Chemical Kinetics Database: Version 5.0; Technical Report; National Institute of Standards and Technology: Gaithersburg, MD, USA, 1993.

70. Fishman, J.; Carney, T.A. A one-dimensional photochemical model of the troposphere with planetary boundary-layer parameterization. J. Atmos. Chem. 1984, 1, 351-376. [CrossRef]

71. Röth, E.P. Description of the Anisotropic Radiation Transfer Model ART to Determine Photodissociation Coefficients; Number JUEL-3960 in Berichte des Forschungszentrums Jülich; Forschungszentrum, Zentralbibliothek: Jülich, Germany, 2002.

(C) 2020 by the authors. Licensee MDPI, Basel, Switzerland. This article is an open access article distributed under the terms and conditions of the Creative Commons Attribution (CC BY) license (http://creativecommons.org/licenses/by/4.0/). 